\title{
https://helda.helsinki.fi
}

Optimising ruminal function: the role of silage and concentrate in dairy cow nutrition to improve feed efficiency and reduce methane and nitrogen emissions

\section{Vanhatalo, Aila}

Burleigh Dodds Science Publishing Limited 2020

Vanhatalo , A \& Halmemies-Beauchet-Filleau , A 2020 , Optimising ruminal function: the role of silage and concentrate in dairy cow nutrition to improve feed efficiency and reduce methane and nitrogen emissions . in C S McSweeney \& R I Mackie (eds), Improving rumen function. Burleigh Dodds Series In Agricultural Science, Burleigh Dodds Science Publishing Limited , pp. 651- 691 . https://doi.org/10.19103/AS.2020.0067.22

http://hdl.handle.net/10138/338740

https://doi.org/10.19103/AS.2020.0067.22

acceptedVersion

Downloaded from Helda, University of Helsinki institutional repository.

This is an electronic reprint of the original article.

This reprint may differ from the original in pagination and typographic detail.

Please cite the original version. 
1 CH22 - Optimising ruminal function: the role of silage and concentrate in dairy cow nutrition to improve feed efficiency and reduce methane and nitrogen emissions Aila Vanhatalo and Anni Halmemies-Beauchet-Filleau, University of Helsinki, Finland Correspondence: aila.vanhatalo@helsinki.fi

Abstract

Ruminant farm animals contribute significantly to global greenhouse gas (GHG) emissions, but the emissions can be greatly reduced by nutrition. Sustainable dairy cow feeding strategy to mitigate GHG and N emissions should make the most of the unique ability of ruminants to convert local human-inedible biomass to high-quality dairy foods. In this chapter, we review the potential of silage plant species (grass, forage legumes, maize) and stage of maturity of silage crops as well as dietary forage to concentrate ratio to reduce environmental footprint of dairy cows in the temperate areas without compromising animal performance. Dairy cow performance is examined in terms of feed intake, milk yield, feed and $\mathrm{N}$ efficiency, and methane emission intensity. The role of concentrate composition (lipids, carbohydrates and protein) is also evaluated. As a case study, the potential of milled rapeseed to reduce environmental footprint of grass silage-based diet is evaluated in practical farm conditions.

Key words: dairy cow, forage species, starch, lipid, methane, nitrogen 
Contents list

1 Introduction

252 Role of silages

2.1 Silage plant species

2.2 Grass silages

2.3 Forage legume silages

2.4 Maize silages

30

2.5 Maize silage vs. grass and forage legume silages

31

3 Role of concentrates

32

3.1 Lipids

\subsection{Carbohydrates}

\subsection{Protein}

354 Case study: Effects of milled rapeseed on milk production, milk fat composition and

36 ruminal $\mathrm{CH}_{4}$ emissions of dairy cows in practical farm conditions

375 Summary and future research perspectives

386 Where to look for further information

397 References 
2

\section{Introduction}

Ruminant farm animals contribute significantly to global greenhouse gas (GHG) emissions including among others enteric methane $\left(\mathrm{CH}_{4}\right)$ and nitrous oxide $\left(\mathrm{N}_{2} \mathrm{O}\right)$. Therefore, a lot of research efforts have been put on finding nutritional means to reduce GHG emissions especially from dairy production sector during recent years. There is a considerable diversity of potential dietary mitigation options under development including not only feeds, feeding management and nutrition but also rumen modifiers i.e. feeding specific substances that directly or indirectly inhibit methanogenesis or using biological control directed at reducing methanogens (Knapp et al., 2014). Some of the feed additives such as $\mathrm{CH}_{4}$ inhibitor 3-nitrooxypropanol (3-NOP) are very promising not only in intensive dairy cow diets (Dijkstra et al., 2018; Van Gastelen et al., 2019), but also in all-forage cattle diets (Martinez-Fernandez et al., 2018). For now these applications are not available in practice. However, nutritional mitigation strategies based on altering forage and concentrate component of the diet are easily available and often more adaptable and applicable into practice than the available rumen modifiers. It has been estimated that potential of feeding and nutrition (including means such as e.g. improved forage quality, feeding grain and dietary lipids) to lower GHG emissions usually range from low to medium (10-30\%) (Hristov et al., 2013; Knapp et al., 2014). However, Hristov et al. (2013) concluded that improving forage quality and the overall efficiency of dietary nutrient use is an effective way of decreasing $\mathrm{CH}_{4}$ emission intensity in terms of $\mathrm{CH}_{4}$ per unit of animal product.

Effectiveness of dietary strategies to mitigate GHG emissions be they forage or concentrate based strategies depends largely on their effects to rumen volatile fatty acid 
(VFA) fermentation pattern. Any change in dietary composition in favour of propionate production reduces $\mathrm{CH}_{4}$ owing to consuming reducing equivalents while diets in favour of acetate and butyrate formation generate $\mathrm{H}_{2}$ for methanogenesis and thus increase $\mathrm{CH}_{4}$ production as reviewed by Knapp et al. (2014). Also other fermentation processes such as rumen protein degradation and assimilation into microbial protein and biohydrogenation of fatty acids taking place in the rumen contribute to the balance of $\mathrm{H}_{2}$. The former results in either a net consumption or net production of $\mathrm{H}_{2}$, while the latter results in net consumption of $\mathrm{H}_{2}$.

As forages are the main component of dairy cow diets local production of high-quality forage is of utmost importance to dairy farmers for maintaining and ensuring profitable milk production. Therefore, the choice of adopting GHG mitigating nutritional strategy appropriate at farm level depends a lot on geographical location of the farm, which largely determines climatic conditions and the forage plant species available for silage making. For instance, in hot regions silage crops are influenced by high temperatures negatively affecting crop yield and nutritive value while in cold regions a short and cool growing season may limit the use of crops such as maize sensitive to cool temperature as reviewed by Bernardes et al. (2018). This is often the case in Northern areas such as in Northern Europe, where grass species rather than use of maize predominate in silage production. According to Bernardes et al. (2018) climatic conditions affect all stages of silage production and utilization temperature being the most limiting factor. Silage production is dependent both on controllable factors e.g. plant species and stage of maturity, harvesting and ensiling methods and use of additives, and uncontrollable climaterelated factors being thus vulnerable to considerable annual variation in silage fermentation quality and nutritive value. 
91 Concentrate-based strategies include increasing proportion of concentrate in the diet and/or altering the type of carbohydrate (e.g. fibre vs. starch) or type of lipid (e.g. fatty acid profile) supplementation in the concentrate. Even though concentrate components such as grains and oilseeds in the diet are not as sensitive to annual changes in nutritive value relative to forages their contribution to dairy cow feed ration affects a lot on dry matter (DM) intake of forages and digestibility of dietary components e.g. fibre in the diet. compromising animal performance.

According to Hristov et al. (2013) inclusion of concentrate feeds in the diet likely decreases $\mathrm{CH}_{4}$ emission intensity particularly when inclusion is above $40 \%$ of dietary DM and rumen function is not impaired. On the hand, decreasing forage to concentrate ratio in dairy cow diets contradicts with endeavours at reducing use of human-edible components such as grains in the dairy cow feed rations. Sustainable dairy cow feeding strategy should make the most of the unique ability of ruminant animals to convert human-inedible biomass to high-quality animal-derived protein foods i.e. milk and meat.

In this chapter, we focus on reviewing recently accumulated literature from dairy cow physiological or milk production studies conducted on silage and/or concentrate supplemented diets including measurements on $\mathrm{CH}_{4}$ production. We look at their dietary effects on the production parameters, feed efficiency (FE), nitrogen use efficiency (NUE) and $\mathrm{CH}_{4}$ emission intensity in dairy cows in temperate zone conditions with emphasis in Europe and North America. We deal among others with the potential of plant species and stage of maturity of silage crops as well as dietary forage to concentrate ratio and concentrate composition to reduce environmental footprint of dairy cow production without 


\section{Role of silages}

\subsection{Silage plant species}

Climatic conditions within the temperate area vary considerably and thus there is a large variation in forage species available for silage making. Major plant species include grasses, forage legumes and maize.

In northern areas, short and cool growing seasons with the rigours of a cold winter limit the choice of perennial grasses and legumes for silage making (Bernardes et al., 2018). The most widely used perennial forage species include timothy (Phelum pratense), perennial ryegrass (Lolium perenne L.) and various fescue species such as meadow fescue (Festuca pratensis) and tall fescue (Festuca arundinacae L.), red clover (Trifolium pratense) and lucerne (Medicago sativa L.) being the major forage legume species available for silage making (Wilkinson and Rinne, 2018; Bernardes et al., 2018). Though the production of lucerne is limited to southern parts of the zone e.g. in Scandinavia advancing climate change may enable its' production further northward in future (Järvenranta et al., 2016). Maize plant (Zea mays L.) is a tropical crop in origin, but as a valuable forage crop it is used wherever maize can grow, from temperate regions to the tropics. It is characterised with high quantities of low-cost starch per hectare coupled with a relatively high concentration of metabolizable energy, which makes this crop very attractive to farmers (Wilkinson and Rinne, 2018). Plant breeders have developed earlier maturing maize varieties, which can be used for whole-crop silage making in northern conditions. Thus, the area of maize cultivation for silage making is gradually expanding to the north the advancing climate change possibly contributing to it as well. The use of 
biodegradable film in cultivation also enable earlier sowing and harvesting of maize in the marginal areas of Northern Europe such as in Scandinavian countries.

Cool-season forage grasses are characterised with high digestibility attributed to low temperature and long day length, which delay lignification of cell walls (Huhtanen et al., 2013; Bernardes et al., 2018). As the decline in the rate of digestibility due to advancing maturity is slower with legumes than grasses mixing of these plant species for silage making is thus beneficial extending the optimal harvesting period of the herbages (Kuoppala, 2010). However, concentration of non-structural carbohydrates (NSC) including water soluble carbohydrates (WSC) and starch of these forages is often low and varies a lot depending on the climatic conditions. It affects ensiling potential and feed value of grass and legume forages and can be manipulated with harvesting time and ensiling methods such as use of additives (Vanhatalo and Jaakkola, 2016). There are also so called high-sugar ryegrass cultivars rich in WSC available for silage making (Moorby et al., 2006).

\subsection{Grass silages}

Of the grass silage management factors altering forage maturity stage at harvest has the greatest $\mathrm{CH}_{4}$-mitigating potential while $\mathrm{N}$ fertilisation rate, use of additives or high-sugar ryegrass cultivars have no effect (Table 1). Feeding ryegrass-timothy (Warner et al., 2016; Warner et al., 2017), ryegrass (Brask et al., 2013a) or timothy (Pang et al., 2018) silage harvested at early relative to late stage of maturity in high-forage dairy cow diets has increased DM intake, energy-corrected milk yield (ECM) and FE considerably and decreased $\mathrm{CH}_{4}$ emission intensity in terms of $\mathrm{g} \mathrm{CH}_{4}$ per $\mathrm{kg} \mathrm{ECM} \mathrm{up} \mathrm{to} 20 \%$ (Warner et al., 
2016; Warner et al., 2017). Moreover, reductions in $\mathrm{CH}_{4}$ with improved silage quality were independent of the DM intake, and were smaller at late rather than early stage of lactation (Warner et al., 2017). They were neither attributable to acetate to propionate ratio, which was unchanged owing to the grass maturity (Brask et al., 2013a; Warner et al., 2016). However, the positive results were achieved at the expense of simultaneously decreasing NUE, which was remarkably high (-35\%) when very early cut leafy stage grass silage was used (Warner et al., 2017) reflecting the much higher crude protein (CP) content of the leafy stage than the late heading herbage. High $\mathrm{N}$ fertilisation rate of grass forage (150 vs. $65 \mathrm{~kg} \mathrm{~N} / \mathrm{ha}$ ) was also in relation to reduced NUE owing to a $5 \%$-unit higher CP content of the silage with high $\mathrm{N}$ fertilisation level (Warner et al., 2016).

The positive DM intake and milk production responses of dairy cows to grass silage harvested at early stage of maturity are well established (e.g. Rinne, 2000; Harrison et al., 2003) as is also the concomitant high $\mathrm{N}$ content of silages leading to losses of $\mathrm{N}$ from animals (e.g. Rinne et al., 1997). Thus, extremely early harvest of grass forage such as that used by Warner et al. (2017) is not recommendable. However, using silages made from early cut primary growth grass improves $\mathrm{FE}$, decreases $\mathrm{CH}_{4}$ emission intensity and ensures good milk production level of high-producing dairy cows though with compromises in NUE. Decreases in $\mathrm{CH}_{4}$ owing to harvest at early maturity stage seem not to be related to rumen fermentation pattern as effects of advancing maturity of ensiled grass on molar proportion of propionate have been small and inconsistent (Harrison et al., 2003; Warner et. al.,2016). High nitrate content in early maturity grass silage (Warner et al., 2016) or e.g. increased microbial growth (Knapp et al., 2014) due to high energy content in early maturity grass silage may possibly have served as an alternative $\mathrm{H}_{2}$ sink to propionate thus explaining decreases in $\mathrm{CH}_{4}$. High-sugar content ryegrass grass silage improved NUE 
190

191

192

193

in all-silage diet (Table 1; Staerfl et al., 2012) in agreement with beef cattle production studies (Merry et al., 2006), but reduced milk production parameters with minor effect on $\mathrm{CH}_{4}$ emission intensity. According to Bertilsson et al. (2018) elevated WSC levels in highsugar ryegrass silage were achieved at the expense of $\mathrm{CP}$ and fibre but their effects on dairy cow performance were minor. However, positive effects were attributed to a more favourable distribution of $\mathrm{N}$ in terms of more $\mathrm{N}$ to milk and faeces and less $\mathrm{N}$ to urine.

Overall, the issue of improving low NUE of grass forage silages clearly warrants further research. Despite earlier positive production responses of silage inoculants to milk production (e.g. Muck et al., 2018), no such effect nor reduced $\mathrm{CH}_{4}$ emission intensity owing to inoculated grass silage was seen in a study of Ellis et al. (2016) (Table 1).

\subsection{Forage legume silages}

Data on the effects of forage legume silages on $\mathrm{CH}_{4}$ intensity in dairy production is scarce (Table 1). Replacing timothy with lucerne in dairy cow diets was not effective in reducing $\mathrm{CH}_{4}$ emissions but led to increased DM intake, impaired FE and especially reduced NUE (Hassanat et al., 2014; Table 1). Inclusion of sainfoin (Onobrychis viciifolia) containing condensed tannins in grass-silage based silage increased DM intake and ECM yield but led only to a minor decrease in $\mathrm{CH}_{4}$ emission intensity (Huyen et al., 2016; Table 1). Replacing mixture of timothy and red clover silage of 70:30 with a mixture of red clover and timothy silage of 70:30 in dairy cows did not affect DM intake, ECM production, FE or $\mathrm{CH}_{4}$ emission intensity but led to a reduction in NUE (Gidlund et al., 2017; Table 1). This is in agreement with findings of Van Dorland et al. (2007) showing that replacing part of ryegrass silage with red or white clover silage did not affect $\mathrm{CH}_{4}$ emissions but slightly enhanced $\mathrm{N}$ losses to the environment. Even so, according to a review of Phelan et al. 
215 (2015) forage legumes have generally resulted in lower $\mathrm{CH}_{4}$ emissions per $\mathrm{kg}$ of milk or meat produced when compared to grasses. However, they emphasise that this occurs only when the forage legume has had higher feed intake and ruminal passage rates than the grasses, or with legumes that contain condensed tannins.

Indeed, results from comparing forage legume and grass silage-based diets in general demonstrate the superior DM intake and milk production potential of forage legumes over grasses (Vanhatalo and Jaakkola, 2016). Moreover, forage legumes are often considered as an economically profitable alternative to grass and/or maize based forages owing to their ability to provide biologically fixed nitrogen, which serves as an effective means to reduce dependence on synthetic $\mathrm{N}$ fertilizers and thus fossil energy (Vanhatalo and Jaakkola, 2016). The higher intake characteristics of legume than grass silages despite lower digestibility have been attributed to their lower fibre content, more rapid fermentation and particle breakdown in the rumen, and higher passage from the rumen (Kuoppala et al., 2009; Kuoppala, 2010; Dewhurst, 2013). Contradictory results on $\mathrm{CH}_{4}$ mitigation potential of forage legumes may be related to the varying silage fermentation quality and proportions of forage legume in the silages studied. It should be noted, that forage legumes are often grown in mixtures with grasses or other plants rather than as pure stands owing to higher annual herbage yield in mixtures (Phelan et al., 2015). Reduced NUE with forage legume-based diets rather than with grass silage diets stems from their 235 inherently high CP concentrations, especially so with lucerne. However, there are also 236 differences between the forage legume species such as red clover and lucerne in their $\mathrm{N}$ 237 fractions, which may differently affect NUE as reviewed by Dewhurst (2013). Clearly, more research is needed on the potential of forage legumes to reduce $\mathrm{CH}_{4}$ emission intensity 239 and their effects on NUE. 


\subsection{Maize silages}

According to Hatew et al. (2016) increasing maturity of whole-plant maize from very early (20\% DM) to late stage (40\% DM) at harvest effectively reduced $\mathrm{CH}_{4}$ emission intensity on high-forage diet but did not affect DM intake, ECM yield, FE or NUE (Table 1). This was caused by the markedly increased starch content, decreased ruminal fractional rate of degradation of starch and decreased neutral detergent fibre (NDF) content with advancing maturity of maize crop. However, despite higher starch intake this was not attributable to that harvesting whole-plant maize at a higher maturity instead of the currently recommended practise (30 to 35\% DM; e.g. Khan et al., 2015) have potential to reduce enteric $\mathrm{CH}_{4}$ emissions.

Maize cultivars developed for potentially higher cell wall digestibility and intake properties (Jung et al., 2011) relative to conventional maize cultivar have been compared recently (DM 40\%, starch $269 \mathrm{~g} / \mathrm{kg} \mathrm{DM)} \mathrm{with} \mathrm{more} \mathrm{digestible} \mathrm{brown} \mathrm{midrib} \mathrm{maize} \mathrm{silage} \mathrm{(BMCS;}$ DM 34\%, starch $283 \mathrm{~g} / \mathrm{kg} \mathrm{DM}$ ) on high-forage diet increased not only DM intake and ECM yield but improved NUE and reduced $\mathrm{CH}_{4}$ emission intensity. Again, reduction in $\mathrm{CH}_{4}$ was not attributed to rumen fermentation pattern, which was unchanged between the treatments. Moreover, it was demonstrated that by using BMCS N excretion in manure reduced and potential $\mathrm{N}$ volatilisation was avoided by shifting $\mathrm{N}$ excretion from urine to faeces. Nevertheless, increased volatile solid content (i.e. degradable organic matter 
excretion) in the manure was observed giving rise to $\mathrm{CH}_{4}$ emissions from manure storage. However, maize silage type (Falkone vs. LG30224) was of little importance in terms of dairy cow performance and $\mathrm{CH}_{4}$ emissions despite the lower rumen NDF digestibility and higher starch content of Falkone in a diet where proportion of maize in the forage was $65 \%$ (De Boever et al., 2016).

Replacing barley silage (DM 32\%, starch $139 \mathrm{~g} / \mathrm{kg}$ DM) completely with maize silage (DM $31 \%$, starch $322 \mathrm{~g} / \mathrm{kg} \mathrm{DM}$ ) increased considerably DM intake, milk yield and NUE, but did not affect FE or $\mathrm{CH}_{4}$ emission intensity (Benchaar et al., 2014; Table 1). However, increasing proportion of maize silage at the expense of barley silage in the diet reduced $\mathrm{CH}_{4}$ energy losses in association with lower ruminal acetate to propionate ratio. The improved NUE with increasing maize silage in the diet was due to decreased urinary losses suggesting low potential for $\mathrm{N}_{2} \mathrm{O}$ and ammonia emissions from manure.

\subsection{Maize silage vs. grass and forage legume silages}

Because of the inherently high energy value and low CP concentration of the maize crop it has been of interest to study whether mixing or replacing grasses or legumes high in CP with maize silage in the diet leads to beneficial environmental effects in terms of increasing NUE and reducing $\mathrm{CH}_{4}$ emission intensity. Replacing grass silage with maize silage (DM $32 \%$, starch $322 \mathrm{~g} / \mathrm{kg} \mathrm{DM}$ ) on restricted high-forage diet improved NUE and reduced $\mathrm{CH}_{4}$ emission intensity but did not affect FE or milk production except for increased milk protein yield (Van Gastelen et al., 2015; Table 1). Reduction in $\mathrm{CH}_{4}$ was not associated with acetate to propionate ratio, which was unchanged between the treatments. Replacing early cut or late cut grass silages in the high-forage diet with maize silage (DM $31 \%$, starch 
$150 \mathrm{~g} / \mathrm{kg}$ DM) had no major effect on DM intake or milk yield, but NUE was improved particularly in relation to early cut grass silage and $\mathrm{CH}_{4}$ emission intensity reduced particularly in relation to late cut grass silage (Brask et al., 2013a; Table 1). Reductions in $\mathrm{CH}_{4}$ were attributed to clearly decreased acetate to propionate ratio in the rumen and to lower ruminal fibre digestibility with maize silage diets.

Increasing proportion of maize in the mixture of grass and maize silage from $25 \%$ to $75 \%$ on 50:50 forage to concentrate ratio diet increased DM intake and milk yield and decreased $\mathrm{CH}_{4}$ emission intensity, while effects on $\mathrm{FE}$ and NUE were variable and more inconsistent (Reynolds et al., 2010; Hammond et al., 2016; Table 1). However, using similar experimental setup Livingstone et al. (2015, Table 1) did not find differences between these silage treatments in any of the parameters mentioned above owing to the exceptionally low NDF content of the grass herbage. Using low-forage diet, Doreau et al. (2014) (Table 1) did neither find any differences in these parameters except for the lower $\mathrm{CH}_{4}$ emission intensity with maize silage diets. Even so, ruminal acetate to propionate ratio was unchanged between the treatments.

Also red clover and lucerne silages have been replaced with maize silage on high-forage diets but with minor effects on DM intake, production parameters and $\mathrm{CH}_{4}$ emission intensity while NUE was clearly improved with maize silages (Hassanat et al., 2013; Benchaar et al., 2015; Arndt et al., 2015; Table 1). In these studies, maize silage maturity varied in range of 36 to $38 \%$ DM and of 290 to $339 \mathrm{~g} / \mathrm{kg} \mathrm{DM}$ starch while starch contents of legumes were less than $18 \mathrm{~g} / \mathrm{kg}$ DM (Hassanat et al., 2013; Benchaar et al., 2015).

Despite unaffected $\mathrm{CH}_{4}$ emission intensity, rumen $\mathrm{pH}$ and ruminal acetate to propionate ratios were clearly decreased when red clover or lucerne was replaced with maize silage 
315 in the diet (Hassanat et al., 2013; Benchaar et al., 2015; Arnd et al., 2015). The positive changes for lower urinary and faecal $\mathrm{N}$ with maize silage at the expense of forage legume 317 silages in these studies would likely result in lower ammonia and $\mathrm{N}_{2} \mathrm{O}$ emissions. Though, the reduced fibre digestion in the rumen with starch containing maize silage diets may lead to increased $\mathrm{CH}_{4}$ emissions from manure storage (Hassanat et al., 2013). It seems that replacing grass or legume forage silages with maize silage consistently leads to environmental benefits such as reducing $\mathrm{CH}_{4}$ emission intensity on high-forage grass silage-based diets, and improved NUE especially on forage legume silages high in CP without compromises in milk production. However, despite increased amounts of starch with reduced $\mathrm{pH}$ and decreased acetate to propionate ratio as expected. For instance, replacing grass silage with maize silage maintained high rumen $\mathrm{pH}$ and increased rumen butyrate in high-forage diet (Van Gastelen et al. 2015). Thus, the reduction in rumen $\mathrm{pH}$ enhancing the production of propionate (Dijkstra et al. 2011) does not necessarily occur in high-forage diet. As maize starch is fairly resistant to rumen fermentation it is susceptible to enzymatic digestion in the small intestine (Owens et al. 1986). Consequently, a possible shift from acetate to butyrate in favour of less $\mathrm{H}_{2}$ production in the rumen (e.g. Moss et al. 2000) and reduced $\mathrm{H}_{2}$ production in the rumen owing to a partial shift of starch digestion to the lower tract may contribute to reduced $\mathrm{CH}_{4}$ production with maize-containing diets. Nevertheless, a critical dietary concentration of starch is likely required to alter ruminal methanogenesis and decrease $\mathrm{CH}_{4}$ production (Hassanat et al., 2013; Van Gastelen et al., 
339 It is interesting that the clearly decreased acetate to propionate ratio with maize silage diets at the expense of forage legume diets (Hassanat et al., 2013; Benchaar et al., 2015; Arnd et al., 2015) did not lead to reduced $\mathrm{CH}_{4}$ emission intensity. This may be related to the type of carbohydrate in forage NDF, which affects $\mathrm{CH}_{4}$ emissions (Arnd et al., 2015). They found that fermentation of maize NDF yielded substantially more $\mathrm{CH}_{4}$ than fermentation of lucerne NDF. Thus, the greater $\mathrm{CH}_{4}$ emission expected from greater amount of NDF in lucerne was counterbalanced by a decreasing emission per gram of lucerne NDF fermented. Similar difference in NDF fermentation between maize and lucerne was found in the study of Hassanat et al. (2013). Moreover, in the study of Brask et al. (2013a) less NDF was digested in the rumen for maize silage than grass silage diets despite a comparable NDF concentration in the diets. Further research on the effects of forage carbohydrate type on $\mathrm{CH}_{4}$ emissions and rumen digestion kinetics is needed. The studies should ideally simultaneously examine rumen fermentation, digestion kinetics and microbiota together with GHG and milk production to give in-depth view on mechanism affecting the rumen function and GHG formation. The positive changes on $\mathrm{N}$ losses owing to increasing proportion of maize in the diet suggest that the dietary shift in forage source from forage legumes to maize silage results in lower $\mathrm{NH}_{3}$ and $\mathrm{N}_{2} \mathrm{O}$ emissions from manure (Hassanat et al., 2013; Arndt et al., 2015).

Nevertheless, it should be emphasised that conclusions about the potential of a feeding strategy to reduce GHG emissions depend also on the level of analysis which may reveal if the strategy is feasible also on the farm and chain level and not only at animal level (Van Middelaar et al., 2013). They found that at animal level increasing maize silage at the expense of grass and grass silage in dairy cow diets is a promising strategy with an immediate effect on GHG emissions. However, application of this strategy to average 
intensive Dutch farms would lead to problems with EU regulations when reducing grassland area. On the other hand, applying this strategy to intensive farm that can reduce its area of grassland would lead to higher emissions owing to land use change i.e. ploughing grassland into maize land.

\section{Role of concentrates}

\subsection{Lipids}

Level of lipid supplementation. Lipid supplements are widely used to increase diet energy density to meet the energy requirements of high-producing dairy cows during early and mid-lactation and to improve energy utilization for milk production. However, dietary lipid content should not exceed 6-7\% in DM (review by Beauchemin et al., 2008), otherwise a depression of DM intake, ruminal fibre digestibility and further milk production may occur thus hampering the advantages of increased diet energy density (Bayat et al., 2017; Halmemies-Beauchet-Filleau et al., 2017). Lipids are also one of the most effective and practicable means to improve milk or meat fatty acid composition and mitigate GHG emissions of ruminants in industrialized countries, but the effectiveness depends on multiple factors. These include level of lipid supplementation, fatty acid profile of lipid supplement (eg. chain length and level of unsaturation), form in which the lipid is given (eg. oil vs. full-fat seeds) and the type of basal diet (reviews by Eugène et al., 2008; Beauchemin et al., 2008; Shingfield et al., 2013; Table 2). To support long-term health of human consumers, the aim is to decrease the proportion of saturated fatty acids and to increase those of cis-monounsaturated fatty acids and omega- 3 fatty acids, and improve 
388

389

390

391

the balance of omega- 6 and omega-3 fatty acids in ruminant products (Shingfield et al., 2013).

Over a broad range of dietary conditions, Martin et al. (2010) reported a mean decrease in $\mathrm{CH}_{4}$ emissions of $3.8 \%$ with each $1 \%$ addition of supplemental lipid in diet DM. One or more mechanisms may contribute to $\mathrm{CH}_{4}$ mitigation potential of different lipids in the rumen. These include lower amount of organic matter (OM) fermented in the rumen (lipid decreases DM intake and/or replaces rumen fermentable ingredients in the ruminant diet), direct toxicity or inhibition of rumen cellulolytic bacteria, methanogens and/or attached protozoa, shift in ruminal fermentation from acetate to propionate that consume rather than produce $\mathrm{H}_{2}$ and biohydrogenation of fatty acids in case of unsaturated lipid supplements (review by Martin et al., 2010).

Medium chain saturated fatty acids. Medium chain saturated fatty acid sources such as myristic acid (14:0) or coconut oil rich in lauric acid (12:0) and 14:0 have reduced ruminal $\mathrm{CH}_{4}$ emission intensity up to $30 \%$ when fed at $3.3-5 \%$ in diet DM for lactating cows. The primary mechanism is probably through decrease in DM intake (Table 2) and fermentable OM content in the rumen (Bayat et al., 2018). Medium chain saturated fatty acids may also exhibit toxic effects on methanogens (Beauchemin et al., 2008) or protozoa (Hristov et al., 2011) and impair fibre digestion (Hollmann et al., 2012), but these effects are inconsistent between studies. Recently Bayat et al. (2018) reported only minor alterations in the diversity of specific microbial taxa and no effect on total quantities of bacteria, methanogenic archaea or ciliate protozoa or fibre digestion despite a significant decrease in ruminal $\mathrm{CH}_{4}$ production. Inclusion of medium chain saturates in the diet in general improves FE and NUE in milk production, but concomitant sharp decrease in ECM yield 
413 (Table 2) together with relatively high price of these lipid supplements make applications in commercial dairy farms unlikely. Furthermore, dietary $12: 0$ and $14: 0$ supplementation increase their incorporation in bovine milk fat (Odongo et al., 2007; Hollman et al., 2012; Bayat et al., 2018) that is a nutritionally undesirable change for human consumers.

Unsaturated fatty acids. Plant unsaturated fatty acids such as oleic acid (18:1n-9) and essential fatty acids linoleic acid (18:2n-6) and $\alpha$-linolenic acid (18:3n-3) are considered beneficial to human health. Thus, their use in dairy cow diets that typically results in increases of these omega-fatty acids in ruminant milk and meat together with a decrease in saturated fatty acids, could be a viable way for $\mathrm{CH}_{4}$ mitigation.

Trials with lactating dairy cows clearly indicate that the effects of lipids on animal performance and rumen methanogenesis are proportional to the level of supply and unsaturation (Table 2). As for saturated fatty acids, the primary mechanism is probably through a decrease in DM intake (Table 2). A dose-response trial by Martin et al. (2016) with three levels of $18: 3 n-3$ rich linseed supplementation up to $5.4 \%$ of lipid in the diet DM decreased ruminal $\mathrm{CH}_{4}$ emission intensity up to $39 \%$ with inconsistent effects at lower levels inherent to differences in the composition of the basal diets. Besides lower level of DM intake, the decrease in enteric $\mathrm{CH}_{4}$ production was attributed to a decreased ruminal acetate to propionate ratio and number of protozoa, whereas the number of ruminal methanogens and fibre digestibility remained unaltered. A modest lipid inclusion (1 to $2 \%$ in diet DM) do not suppress feed intake yet, but it already alters milk fatty acid composition (Halmemies-Beauchet-Filleau et al., 2011). At a 5\% lipid inclusion level in diet DM, rapeseed rich in 18:1n-9 and 18:2n-6 sources safflowerseed, sunflowerseed and camelina seed have resulted in much less pronounced decreases in $\mathrm{CH}_{4}$ emission intensity 
compared to linseed at best reaching a $23 \%$ decrease (Table 2). In most studies presented in Table 2 the experimental periods are of 4 to 6 weeks, but recently Alstrup et al. (2015) demonstrated that plant lipids suppress ruminal methanognesis throughout the entire lactation. However, more studies comprising entire lactation are needed to confirm the persistency of lipids to mitigate ruminal $\mathrm{CH}_{4}$ emissions.

It is generally thought that intact oilseeds give a partial protection for oil against microbial metabolism or limits the effects of oil on ruminal microbes and nutrient digestibility or both. However, Martin et al. (2008) reported no difference in OM and fibre digestibility between whole intact linseed, extruded linseed and linseed oil diets. Though pure oil is often more effective to mitigate $\mathrm{CH}_{4}$ production in the rumen, processed oilseeds (e.g. crushed by milling, extruded, pressed cakes) are preferred because of less adverse effects on DM intake and generally lower price (Beauchemin et al., 2008; Table 2). In addition, administering high levels of dietary unsaturated fatty acids as a part of total mixed ratio (TMR) results in a lower decrease in DM intake (Bayat et al., 2015) than incorporation into concentrates fed separately to forage (Halmemies-Beauchet-Filleau et al., 2017). This is probably due to a more sudden pulsitary release of unsaturated fatty acids in the rumen in separate feeding relative to TMR as high amounts of free unsaturated fatty acids are toxic to cellulolytic bacteria (Maia et al., 2007).

Basal diet greatly affects the production and enteric $\mathrm{CH}_{4}$ emission response to lipids. On forage predominant diets (diets rich in fibre) based on $50 \%$ or more in diet DM of grass silage, red clover silage or grass hay, unsaturated lipid supplements up to $5 \%$ in diet DM in general maintain ECM yield and improve FE. Furthermore, there is a dose-dependent and consistent decrease in ruminal $\mathrm{CH}_{4}$ emissions (Table 2). In contrast, on starchy diets (diets 
based on maize silage or rich in concentrate starch), the ECM yield and FE are often compromised already at low lipid inclusion levels (2-4\% in diet DM) and the effects on ruminal $\mathrm{CH}_{4}$ emissions are variable between studies (Table 2). At high lipid inclusion levels (4-5.5\% in diet DM), ruminal $\mathrm{CH}_{4}$ emission intensity is more consistently reduced, but the reduction is often accompanied by a decrease in ECM production (Table 2). Therefore, unsaturated lipid supplements to mitigate $\mathrm{CH}_{4}$ emissions suit best for diets rich in fibre, but their use in starchy diets is of limited interest due to the negative effects on ECM yield. This is probably linked to a much more detrimental effect of unsaturated lipid on rumen fibre digestion on diets high in starch relative to high fibre diets leading to a decrease in acetate formation in the rumen and further milk fat content (Benchaar et al., 2015; Bayat et al., 2017). In addition, PUFA supplementation on starchy diet readily directs rumen biohydrogenation from trans-11 to trans-10 route, some trans-10 isomers being potential antilipogenic agents in the bovine mammary gland thus causing milk fat depression (MFD; review by Shingfield et al., 2010; Ventto et al., 2017).

Feed $\mathrm{N}$ use efficiency in milk protein synthesis is in general unaltered or slightly improved by unsaturated lipid supplements in the diet (Table 2). Though milk protein content or yield may in some cases decrease by lipid in the diet so do the feed and CP intakes (Benchaar et al., 2015; Halmemies-Beauchet-Filleau et al., 2017; Bayat et al., 2018), which explains the unaffected or improved conversion efficiencies. The possible decrease in milk protein synthesis due to lipid supplementation has been attributed to the negative effects on energy intake, limitation in glucose supply and microbial protein synthesis (review by Lock and Shingfield, 2004; Halmemies-Beauchet-Filleau et al., 2017). 
487 Eicosapentaenoic acid (20:5n-3) and docosahexaenoic acid (22:6n-3) present in fish oil or

488

489

490

491

492

493

494

495

496

497

498

499

500

501

502

503

504

505

506

507

508

509

510

511

specific algae products have had a strong $\mathrm{CH}_{4}$ supressing effect when tested in vitro

(Martin et al., 2010). However, when fed at low levels (up to $1 \%$ in diet DM) to lactating

dairy cows, ECM yield together with FE have already decreased without any improvement

in ruminal $\mathrm{CH}_{4}$ emissions. This suggest that lipid supplements rich in 20- and 22-carbon polyunsaturated fatty acids are not a useful tool to mitigate the GHG emissions of dairy cows in practice.

\subsection{Carbohydrates}

Level of concentrate supplementation. Decreasing forage to concentrate ratio (i.e. an increase in concentrate starch inclusion) in the dairy cow diet generally improves feed intake (Table 3) due to the reduced contribution of forage fibre with high bulk density (review of Allen, 2000). In addition, the greater proportion of concentrates in the diet may be associated with more extensive OM digestion in the rumen reflecting the greater inherent digestibility of NSC in concentrates (starch and sugars) relative to structural forage carbohydrates (hemicellulose and cellulose; Bayat et al., 2017). Consistent with this concentrate level in the diet is often an increase in the total tract digestibility of starch, but fibre digestibility is also often simultaneously impaired (Niu et al., 2016; Bayat et al., 2017) that may level out the overall impact of starchy concentrate on OM digestibility. The changes in feed intake are reflected in ECM production leading to unaffected FE except for lipid-rich diets (Table 3). There is a trend for an increase in milk protein and a decrease in milk fat in response to concentrate supplementation (Aguerre et al., 2011; Niu et al., 2016; Bayat et al., 2017). The increase in milk protein may be driven by greater inclusion of cereals with high metabolizable energy density in the diet. As the level of starchy 
concentrate in the diet increases, there is a concomitant decrease in forage intake and thus forage fibre. The ruminal fermentation of NDF results in lipogenic VFA in the rumen that may account for the decrease in milk fat on diets low in forage.

The low and high concentrate diets reported in Table 3 were all isonitrogenous (CP 15$18 \%$ in DM) except for Olijhoek et al. (2018), where high concentrate diet had a $20 \%$ higher $\mathrm{CP}$ content relative to a low forage diet leading to a reduced NUE. The general improvement in NUE on concentrate rich diets (Table 3) is probably a result of a better balance of degradable protein and energy available for microbes in the rumen as indicated by lower rumen ammonia concentrations in high concentrate diets (Bayat et al., 2017) and higher relative contribution of good quality protein feeds in dietary protein.

The reduction of ruminal $\mathrm{CH}_{4}$ production at increasing levels of concentrate in the diet is well established (Table 3; Martin et al., 2010). Cattle $\mathrm{CH}_{4}$ emissions are rather constant for diets containing up to $30-40 \%$ of concentrate in $\mathrm{DM}$, then decreasing rapidly to low levels for diets containing $80-90 \%$ concentrate (Martin et al., 2010) common in some beef production systems. Replacing forage structural (fibrous) carbohydrates with NSC (starch and sugar) in concentrates drives changes in rumen physico-chemical environment and microbial populations favouring starch-fermenting microbes and propionate formation (Martin et al., 2010). However, even marked reductions in ruminal $\mathrm{CH}_{4}$ formation are not always accompanied by a shift towards propionate in the rumen VFA (Aguerre et al., 2011). The forage in their study was a mixture of maize and grass silage and rumen fermentation pattern in cattle fed grass silage-based diets appears to be rather resistant to increased concentrate supplementation (Huhtanen et al., 2013). On the other hand, Bayat et al. (2017) reported a significant decrease in acetate to propionate ratio (-28\%) and $\mathrm{CH}_{4}$ 
537

emission intensity $(-25 \%)$ in response to increased concentrate supplementation from 35 to $65 \%$ in the diet DM on grass silage-based diets. However, when the diet contained supplemental lipids there was no decrease in $\mathrm{CH}_{4}$ despite a marked decrease in acetate to propionate ratio $(-22 \%)$ that was similar to the decrease on unsupplemented diet. It should be noted that the VFA concentrations in the rumen fluid do not directly reflect the VFA production, but the ruminal balance of production and absorption of VFA. This may contribute to the apparent inconsistencies between the VFA profile in the rumen fluid and ruminal $\mathrm{CH}_{4}$ production in some cases as speculated by Aguerre et al. (2011).

In addition to rumen fermentation pattern, the reduction of rumen $\mathrm{pH}$ in high concentrate diets may also contribute to decreased ruminal $\mathrm{CH}_{4}$ production via the decrease of protozoal numbers (Martin et al., 2010) or direct inhibition of methanogenesis below pH 6 (Van Kessel and Russell, 1996) or both. Although inclusion of high levels of concentrate in the diet of dairy cows is an effective $\mathrm{CH}_{4}$ mitigation strategy (Table 3), it has disadvantages associated with increased risk for sub-acute rumen acidosis (SARA, review by Krause and Oetzel, 2006), competition with human food sources, GHG emissions during grain production and high feed cost. In addition, fibrous forage rather than starchy concentrate is the predominant natural part of the cattle diet they are specialised to utilize.

\section{Carbohydrate source. Fibrous, human inedible by-products of food and bioenergy} industries to partly or totally replace starch-rich cereal grains in the diet of high-producing dairy cows could provide a cost-effective and ethically sound feeding strategy that promote also circular economy. In addition, fibre-rich diets promote rumen and animal health as starch and other readily fermentable carbohydrates are at high amounts known to greatly 
561

562

563

564

565

566

567

568

569

570

571

572

573

574

575

576

577

578

579

580

581

582

583

584

585

modify the rumen environment through a decrease in $\mathrm{pH}$ and, consequently, to predispose to SARA (Krause and Oetzel, 2006).

Feeding dairy cows a fibre-rich concentrate with pulps, soya bean hulls or to some extent cereal bran as main carbohydrate ingredient has resulted in similar DM intakes, ECM production, FE and NUE as concentrates rich in cereal starch under variable isonitrogenous dietary conditions in terms of forage to concentrate ratio and forage type (Table 4). It should, however, be noted that all these trials were made in mid- to late lactation and the ECM production was around $30 \mathrm{~kg} / \mathrm{d}$. Therefore, at higher milk production and nutrient demand levels in early and at peak lactation, the results on animal performance may be different. At early lactation (30 days in milk), Piccioli-Cappelli et al. (2014) reported no difference in DM intake or lactation performance between dairy cows fed diets low or high in readily fermentable carbohydrates (starch plus sugars 18 vs $25 \%$ in diet DM, milk yield level $37 \mathrm{~kg} / \mathrm{d}$ ). However, the alterations in the concentrations of energy metabolites and hormones in blood together with body weight loss indicated mobilization of body reserves in low-starch diet relative to high-starch diet that in contrast resulted in positive energy balance and some body weight gain. It seems that a large proportion if not all cereal starch can be replaced by fibrous by-products of high digestibility such as sugar beet pulp and soya bean hulls up to milk production level of 30 $\mathrm{kg} / \mathrm{d}$ without a significant decrease in dairy cow lactation performance. Furthermore, Cabezas-Garcia et al. (2017) demonstrated recently that it is possible to replace barley and late-cut grass silage with early-cut grass silage of high energy value without compromising ECM yield, NUE and $\mathrm{CH}_{4}$ emission intensity. In their study, the proportion of concentrate in the diet DM incrementally decreased from 60 to $45 \%$ and the starch from 25 to $17 \%$, whereas NDF gradually increased from 36 to $42 \%$. 
587 Though Benchaar et al. (2001) modelled that replacing fibrous concentrate with starchy 588 one reduces $\mathrm{CH}_{4}$ emissions, a critical dietary concentration of starch of 20 to $22 \%$ in DM 589 is required to mitigate ruminal methanogenesis (Tables 3 and 4; Hassanat et al., 2013). 590 On lipid supplemented diets, however, even a dietary starch content of $28 \%$ in DM did not 591 alter ruminal $\mathrm{CH}_{4}$ formation (Pirondini et al., 2015 Table 4; Bayat et al., 2017 Table 3). The 592 decrease in ruminal protozoa population and the shift of rumen fermentation towards 593 propionate seem to be the main factors for reduced $\mathrm{CH}_{4}$ emission intensity on starchy 594 concentrate diets (Pirondini et al., 2015; Bougouin et al., 2018). Though high-starch diets 595 596 597 598 599 600 601 602 603 604 605 606 607 608 609 610 are promising in mitigating $\mathrm{CH}_{4}$ emission intensity of dairy cattle, the level of cereal starch needed to obtain significant reduction is very high. This contradicts with the uniqueness of ruminants to convert fibrous biomass inedible to monogastrics to high-quality human food.

\subsection{Protein}

Level of protein supplementation. Conventional good quality protein sources rapeseed and soya bean meals typically increase DM intake of dairy cows (meta-analysis of Huhtanen et al., 2011) though the effect has been negligible in some cases (Table 4). The increase in feed intake may at least in part be attributed to improved digestibility of dietary fibre and CP (Broderick, 2003; Jaakkola et al., 2009), but better amino acid balance of conventional protein feeds or increased nutrient demand due to higher milk production may also contribute (Gidlund et al., 2017). The improved ECM and milk protein yields in response to good quality $\mathrm{CP}$ supplementation probably results from higher supply of essentials amino acids to mammary gland (Gidlund et al., 2017). However, the increase in ECM production above dietary CP content of $14-15 \%$ is in general rather moderate and 
611

612

613

614

615

616

617

618

619

620

621

622

623

624

625

626

627

628

629

630

631

632

633

634

635

seem to level out or even decline at high dietary CP concentrations above $18-20 \%$ (Table 4; Broderick, 2003). Interestingly, the production responses of rapeseed meal have been similar irrespective of a wide range of forage CP concentration (Jaakkola et al., 2009;

Gidlund et al., 2017 in Table 4). Replacing soya bean meal with dehydrated lucerne also resulted in lower (-7\%) milk yield (Doreau et al., 2014). All this indicates the superiority of protein in rapeseed and soya bean to that in forage to enhance milk production.

Dietary CP concentration is the best predictor of NUE in dairy production (meta-analysis by Huhtanen and Hristov, 2009). Indeed, the linear decrease of NUE in response to incremental supply of dietary CP is consistently reported (Table 4) the efficiency typically ranging between 40 and 20\% (Dijkstra et al., 2011). With low protein diets, faecal N excretion represents a larger proportion of $\mathrm{N}$ intake (up to $50 \%$ ) than urine $\mathrm{N}$ (as low as $25 \%$ ), but as dietary protein continue to increase the contribution of faecal $\mathrm{N}$ decreases and the environmentally labile urinary $\mathrm{N}$ exponentially increases up to $60 \%$ of $\mathrm{N}$ intake (Dijkstra et al., 2011). In part this is related to the failure of the rumen microbes to utilise the extra degradable protein since the primary route of removing excess ammonia from the rumen is conversion to urea in the liver, followed by excretion in urine (Castillo et al., 2000).

The most obvious reason why increased dietary level of CP could in theory reduce ruminal $\mathrm{CH}_{4}$ emissions was that the fermentation of protein produces less $\mathrm{CH}_{4}$ than that of carbohydrates (Bannink et al., 2006). The potential to decrease ruminal $\mathrm{CH}_{4}$ emissions intensity by increased protein supplementation has been small in practise; the low to medium inclusion level of protein feed resulting in the smallest ruminal $\mathrm{CH}_{4}$ emission intensity (at best around -15\%) together with the biggest improvement in lactation 
636

637

638

639

640

641

642

643

644

645

646

647

648

649

650

651

652

653

654

655

656

657

658

659

660

performance (Table 4). The excess of dietary $\mathrm{CP}$ in dairy cow ratios is unnecessary and unwanted since the protein feeds are expensive and the improvement in milk and $\mathrm{CH}_{4}$ production are diminishing or even inverse at the highest CP levels (Table 4) leading only to more significant $\mathrm{N}$ load to environment via manure and urine.

Protein source. Inclusion of rapeseed meal in dairy ratios generally increases DM intake, ECM yield and milk protein yield to a larger extent relative to soybean meal (review by Huhtanen et al., 2011; Table 4) and to other protein sources (review by Martineau et al., 2013). Huhtanen et al. (2011) suggested that the greater milk production responses with rapeseed meal is due to increased or more balanced amino acid supply (histidine in particular) or both, the greater energy demand for milk production pulling also DM intake. All this also results in slightly improved NUE in rapeseed supplemented diets relative to soya bean (Table 4). The reports comparing the effects of rapeseed meal to soya bean on enteric $\mathrm{CH}_{4}$ production are scarce. Gidlund et al. (2015; Table 4) reported a marginal decrease in $\mathrm{CH}_{4}$ emission intensity on rapeseed relative to soya bean meal across a wide range of dietary $\mathrm{CP}$ contents.

Grain legume faba bean (Vicia faba) and pea (Pisum sativum) seeds are relatively rich in protein $(23-30 \%$ of DM) and starch (45-50\% of DM) making them an interesting homegrown protein and energy source for dairy cow feeding in the temperate areas. However, the protein of these alternative grain legumes is more rumen degradable and lower in methionine than that of rapeseed or soybean, which may limit the lactation performance of dairy cows (review by Halmemies-Beauchet-Filleu et al., 2018). Replacing protein in soya bean meal partially or completely with faba beans or peas has, however, resulted in rather similar bovine lactation performances (Halmemies-Beauchet-Filleau et al., 2018, Table 4). 
661 In contrast, the milk production responses of alternative grain legumes are often inferior

662

663

664

665

666

667

668

669

670

671

672

673

674

675

676

677

678

679

680

681

682

683

684

685

compared to the rapeseed meal (Halmemies-Beauchet-Filleau et al., 2018; Table 4).

Puhakka et al. (2016) reported a decreased milk protein yield together with an increased milk urea concentration and the proportion of $\mathrm{N}$ excreted in urine suggesting less efficient use of protein in faba beans than in rapeseed leading to increased $\mathrm{N}$ emissions to environment. However, the NUE of alternative grain legumes seems rather similar to soya bean and rapeseed meal in most of the studies (Table 4). It can be speculated that the inclusion of faba beans or peas in the dairy cow diet could increase starch intake and shift rumen fermentation towards propionate thus mitigating ruminal $\mathrm{CH}_{4}$ production, but in recent studies (Ramin et al., 2017; Cherif et al., 2018; Johnston et al., 2019) the effect on $\mathrm{CH}_{4}$ emission intensity has been negligible (Table 4).

\section{Case study: Effects of milled rapeseed on milk production, milk fat composition} and ruminal $\mathrm{CH}_{4}$ emissions of dairy cows in practical farm conditions

Introduction. Besides mitigating ruminal $\mathrm{CH}_{4}$ production unsaturated lipids such as 18:1n9 rich oil from rapeseeds have great potential to modify lipid composition of ruminant meat and milk by decreasing the proportion of saturated fatty acids and increasing that of unsaturated fatty acids inherent to lipid supplement. This is noteworthy as milk and dairy products contribute significantly to human 12:0, 14:0 and palmitic acid (16:0) consumption, excessive intake of these saturated fatty acids predisposing to cardiovascular disease as well as lowered insulin sensitivity (review by Shingfield et al., 2013). The form of lipid inclusion in the dairy cow diet affects lipid bioavailability and final product composition. Milling of rapeseeds was necessary to release lipids within seeds for efficient absorption (Kairenius et al., 2009). Furthermore, milled rapeseeds in the diet resulted in a similar fatty 
686

687

688

689

690

691

692

693

694

695

696

697

698

699

700

701

702

703

704

705

706

707

708

709

acid profile in bovine milk as free rapeseed oil with the exception of lower increase in trans fatty acids. In dairy farms, milling whole oilseeds according to consumption also minimises the risk for oxidative deterioration of unsaturated lipid during the feed component storage relative to pure oil. The aim of this study was therefore to examine the effects of milled rapeseed on milk fat composition and ruminal $\mathrm{CH}_{4}$ emissions of dairy cows in practical farm conditions.

Materials and methods. The dairy cow study was conducted at the University of Helsinki, Viikki research farm in Finland (for details see Halmemies-Beauchet-Filleau et al., 2019). In brief, the whole Finnish Ayrshire herd in milk was fed a control diet for 3 weeks (Period 1) followed by rapeseed lipid-rich diet of 4 weeks (Period 2). After this, all cows were switched back to the control diet (3 weeks, period 3). Forage-rich dairy cow TMR based on high quality grass silage (digestible OM $696 \mathrm{~g} / \mathrm{kg}$ DM, 60\% in TMR DM) were fed ad libitum. The pre-wilted grass silage (predominantly timothy and meadow fescue) was of 1st cut and ensiled with formic acid-based additive in big bales. Concentrates in TMR $(40 \%$ in TMR DM) comprised of home-grown cereals, rapeseed feeds as protein supplement, molassed sugar beet pulp and vitamins and minerals. Rapeseed protein was isonitrogenously supplied either as a lipid extracted meal (control diet) or full-fat seeds milled daily during TMR preparation using an ordinary hammer mill (sieve pore size 6 to 8 $\mathrm{mm}$ ) (test diet). The amount of additional rapeseed lipids in the test diet was ca. $50 \mathrm{~g} / \mathrm{kg}$ diet DM. Cereal in the control diet was barley and in the test diet oats. When visiting the milking-robot (Lely Astronaut A3, Lely, Maassluis, The Netherlands), cows producing less than 30 , between 30 and 40 and over $40 \mathrm{~kg}$ of milk per day at the beginning of the trial received 3,4 or $5 \mathrm{~kg}$ of standard concentrate per day throughout the study. The milking 
710

711

712

713

robot was equipped with GreenFeed system (C-Lock Inc., Rapid City, SD, USA) that measures ruminal $\mathrm{CH}_{4}$, carbon dioxide and $\mathrm{H}_{2}$ emissions.

Results and discussion. Cows had no health concerns when fed the test diet, but DM intake was decreased by on average $4 \%$ relative to control diet (for details see Halmemies-Beauchet-Filleau et al., 2019). This is not unexpected because lipid supplementation often suppresses DM intake at high inclusion rates (review of Huhtanen et al., 2008; Halmemies-Beauchet-Filleau et al., 2017). As ECM was unaffected by the test diet, the FE was marginally improved from 1.34 to 1.40 (ECM kg per DM intake kg) compared with control diet. Protein yield and milk urea content were also unaffected by the form of rapeseed protein in the diet. Though test diet had no effect on milk fat yield, it altered milk fat composition (Table 5). The total saturated fatty acid content of milk fat from the test diet was $17 \%$ lower than from the control diet (Table 5). Furthermore, the 10- to 16-carbon saturated fatty acids, regarded as the key blood cholesterol-increasing fatty acids in humans, were substantially lower in milk from the test than in the milk from the control diet. Indeed, increased supply of long-chain fatty acids is known to inhibit de novo synthesis of saturated fatty acids in the mammary gland (review of Shingfield et al., 2010). The total monounsaturated fatty acids were $58 \%$ higher in milk fat from the test diet than the control diet that principally originated from 18:1n-9. The effect of milled rapeseeds on polyunsaturated fatty acids in milk was marginal. Furthermore, milk fat and fat-rich dairy products with a high monounsaturated fatty acid content are less susceptible to oxidative deterioration (Lin et al., 1996) compared with milk fat enriched with polyunsaturated fatty acids (Havemose et al., 2006). 
734 Ruminal $\mathrm{CH}_{4}$, carbon dioxide and $\mathrm{H}_{2}$ emissions were decreased by 18,5 and $36 \%$,

735

736

737

738

739

740

741

742 respectively on the test diet relative to control. Thus, milled rapeseeds substantially decreased $\mathrm{H}_{2}$ load and $\mathrm{CH}_{4}$ formation in the rumen of dairy cows fed diets rich in highly digestible grass silage (Figure 1). The small decrease in DM intake cannot account for all the diminution in the ruminal $\mathrm{H}_{2}$ and $\mathrm{CH}_{4}$ emissions observed in the test diet. It is likely that the rumen fermentation pattern shifted towards propionate that increases $\mathrm{H}_{2}$ utilisation.

Rapeseed or other unsaturated lipids in the dairy cow diet have decreased ruminal acetate to propionate ratio in some (Hristov et al., 2011; Table 2), but not in all studies (Table 2). Though ruminal biohydrogenation of unsaturated fatty acids is an alternative $\mathrm{H}_{2}$ sink as well, its significance to the overall ruminal methanogenesis is generally considered very low (Martin et al., 2010). The $\mathrm{CH}_{4}$ emission intensity was 12.1 vs. $15.1 \mathrm{~kg} \mathrm{CH}_{4}$ per $\mathrm{kg} \mathrm{ECM}$ for test and control diet, respectively. In an average dairy herd in Finland that produces 10 300 ECM per year per cow and has 45 dairy cows a change from control diet typical to the production system in the area to test diet would thus represent an annual decrease of 1 $390 \mathrm{t}$ in ruminal $\mathrm{CH}_{4}$ emissions. This corresponds to the withdrawal of $\mathrm{CH}_{4}$ production of the whole herd of about 2 months in a year.

Conclusions. Replacing rapeseed meal with milled rapeseeds (supplying $5 \%$ of lipid in diet DM) in a dairy cow diet based on highly digestible grass silage had no adverse effects on milk production, FE or animal health. Milled rapeseeds improved milk fat profile by decreasing the proportion of cholesterol-raising medium-chain saturated fatty acids and increasing that of 18:1n-9 in a whole herd level. In addition, milled rapeseeds fed at a commercially practical level substantially suppressed ruminal $\mathrm{CH}_{4}$ production. 
Acknowledgements. This study was financed in part by the European Institute of Innovations and Technology (EIT) (EIT Food Project 18095: Dairy products with reduced saturated fatty acids) and made in co-operation with Valio Ltd and the University of Reading.

\section{Summary and future research perspectives}

Nutritional strategies available for mitigating GHG emissions from dairy cow production include various rumen modifiers under development and forage and/or concentrate based dietary strategies currently more flexibly available and applicable in practice. Given the ambition for reducing human-edible feed ingredients such as grains in animal feeding forage-based dietary strategies should be stressed especially with ruminant animals specialized in fibre digestion. In temperate areas, major plant species available for silage making include grasses, forage legumes and maize crop but their availability in various areas depend a lot on local climatic conditions.

Grass silages. Altering forage maturity at harvest has the greatest potential to reduce environmental footprint of cool-season grass silages in dairy production. Harvesting grass herbage at early rather than late maturity stage has led to increased DM intake, ECM, FE and reduced $\mathrm{CH}_{4}$ emission intensity with dairy cows, though at the expense of reduced NUE. The trade-offs between reduced $\mathrm{CH}_{4}$ emissions and reduced NUE are complex and clearly warrant further research. Other management factors such as $\mathrm{N}$ fertilization rate, use of additives in ensiling or high-sugar grass cultivars were of minor importance. 
Forage legume silages. Limited data on the effects of forage legume silages on $\mathrm{CH}_{4}$ emission intensity in comparison to grasses together with reduced NUE suggest minor potential for forage legumes to reduce environmental footprint of dairy production. In contrast, literature suggests lower $\mathrm{CH}_{4}$ emission intensity for forage legumes than grasses provided that higher DM intake potential and ruminal passage rates characteristic to forage legumes occur. Contrasting results may be attributable to practice of growing and feeding forage legumes in mixtures with grasses or other plants as well as large variation in silage nutritive and fermentation quality between years. Further research on potential of forage legumes to reduce environmental footprint of dairy production is needed to fully exploit their beneficial effects on forage production, feed DM intake and animal performance.

Maize silages. Starch containing maize silage can be characterized with high metabolizable energy and low CP contents, which makes it a highly valuable forage crop and compatible to be mixed with grasses and legumes higher in CP. The means available for reducing environmental footprint of maize silage include advancing maturity of maize crop at harvest to late stage ( $40 \% \mathrm{DM})$ and using maize cultivars developed for higher cell wall digestibility and intake properties such as brown midrib maize. These methods may have potential to reduce $\mathrm{CH}_{4}$ emission intensity up to $10 \%$ on high-forage diets. Replacing grass or legume forage silages with maize silage consistently leads to environmental benefits in terms of reducing $\mathrm{CH}_{4}$ emission intensity on high-forage grass silage based diets, and improving NUE especially on forage legume silages high in CP without compromises in milk production. Nevertheless, further research is needed to optimize the use of these forages in dairy production. Especially, more research on the effects of forage legume $\mathrm{N}$ fractions on NUE and forage carbohydrate type on $\mathrm{CH}_{4}$ 
emissions are warranted. Moreover, chain level analyses comparing environmental effects of maize and perennial silage crops are needed.

Lipids in concentrate. Unsaturated plant lipids at inclusion levels up to $5 \%$ in diet DM have potential to mitigate ruminal $\mathrm{CH}_{4}$ emissions in a dose dependent manner by $20-40 \%$ on diets based on conserved grass or forage legumes without negative effects on animal performance in terms of ECM yield and FE. The effect of lipids seems to persist throughout the entire lactation, but more long-term studies are needed to confirm the persistency. At high lipid inclusion rates, feeding lipid as a part of TMR is preferred to separate concentrate feeding. In contrast, on starchy diets (based on maize silage or rich in concentrate starch) lipid supplementation is of limited interest due to the negative effect on ECM yield. This is probably linked to more detrimental effect of unsaturated lipid on rumen fibre digestion when basal diet contains significant amounts of starch.

Carbohydrates in concentrate. Increasing the proportion of cereal starch in the dairy cow diet in general improves feed intake, ECM yield and NUE. A critical dietary concentration of starch of $20-22 \%$ in the diet DM is required to mitigate ruminal methanogenesis and decreases of $20-25 \%$ have been reported, when the starch content has reached $20-32 \%$ in the diet DM. However, high inclusion of readily fermentable carbohydrates from cereals predisposes to SARA and competes with human nutrition. Fibrous, human inedible byproducts of food and bioenergy industries provide a cost-effective and ethically sound feeding strategy that promote also circular economy. Soya bean hulls, sugar beet pulp and cereal bran have partly or totally replaced starch-rich cereal grains in the diet of dairy cows without a decrease in animal performance or increase in ruminal $\mathrm{CH}_{4}$. However, the production level of mid-lactation cows has not exceeded $30 \mathrm{~kg} / \mathrm{d}$ in these studies, so more 
831

832

833

834

835

836

837

838

839

840

841

842

843

844

845

846

847

848

849

850

851

852

853

854

855

research is needed at higher levels of milk production and at early lactation to confirm these promising findings.

Protein in concentrate. Good quality protein sources rapeseed and soya bean meals typically increase DM intake of dairy cows though the effects have been negligible in some cases. The low to medium inclusion level of protein feed (dietary CP content of $15-18 \%$ depending on the $\mathrm{CP}$ of the basal forage) results in the smallest ruminal $\mathrm{CH}_{4}$ emission intensity (at best around -15\%) together with the biggest improvement in lactation performance. The excess of dietary CP in dairy cow ratios (CP above $18-20 \%$ in $D M)$ is unnecessary and unwanted since the protein feeds are expensive and the improvement in milk and $\mathrm{CH}_{4}$ production are diminishing or even inverse at the highest CP levels leading only to a more significant $\mathrm{N}$ load to environment via manure, urine in particular.

Interestingly, the protein in conventional dairy cow protein feeds rapeseed and soya bean is superior to that in forage to enhance milk production. Furthermore, rapeseed protein is slightly superior to soya bean, and faba bean and pea in terms of lactation performance, but in ruminal $\mathrm{CH}_{4}$ emissions the differences between these protein sources are negligible. Faba beans and peas are promising home-grown protein and energy sources for dairy cow feeding in the temperate areas due to their relatively high CP and starch content. More research is needed to find ways to improve the CP utilization of forage and alternative grain legumes to improve their NUE in milk production.

\section{Where to look for further information}

The following review articles or meta-analysis provide a good overview of the subject: 
856 Dewhurst, R. J. (2013), Milk production from silage: comparison of grass, legume and maize silages and their mixtures, Agric. Food Sci. 22: 57-69.

858 Huhtanen, P. and Hristov, A. N. (2009), A meta-analysis of the effects of dietary protein concentration and degradability on milk protein yield and milk $\mathrm{N}$ efficiency in dairy cows, J. Dairy Sci. 92: 3222-3232.

861

862

863

864

865

866

867

868

869

870

871

872

873

874

875

876

877

878

879

Hristov, A. N., Oh, J., Firkins, J. L., Dijkstra, J., Kebreab, E., Waghorn, G., Makkar, H. P. S., Adesogan, A. T., Yang, W., Lee, C., Gerber, P. J., Henderson, B. and Tricarico, J. M. (2013), Special topics-Mitigation of methane and nitrous oxide emissions from animal operations: I. A review of enteric methane mitigation options, J. Anim. Sci. 91: 5045-5069.

Ramin, M. and Huhtanen, P. (2013), Development of equations for predicting methane emissions from ruminants, J. Dairy Sci. 96: 2476-2493.

\section{References}

Aguerre, M. J., Wattiaux, M. A., Powell, J. M., Broderick, G. A. and Arndt, C. (2011), Effect of forage-to-concentrate ratio in dairy cow diets on emission of methane, carbon dioxide, and ammonia, lactation performance, and manure excretion, J. Dairy Sci. 94: 3081-3093.

Allen, M. S. (2000), Effects of diet on short-term regulation of feed intake by lactating dairy cattle, J. Dairy Sci. 83: 1598-1624.

Alstrup, L., Hellwing, A. L. F., Lund, P. and Weisbjerg, M. R. (2015), Effect of fat supplementation and stage of lactation on methane production in dairy cows, Anim. Feed Sci. Technol. 207: 10-19. 
Arndt, C., Powell, J. M., Aguerre, M. J. and Wattiaux, M. A. (2015), Performance, digestion, nitrogen balance, and emission of manure ammonia, enteric methane, and carbon dioxide in lactating cows fed diets with varying alfalfa silage-to-corn silage ratios, $\mathrm{J}$. Dairy Sci. 93: 418-430.

Bannink, A., Kogut, J., Dijkstra, J., France, J., Kebreab, E., Van Vuuren, A. M. and Tamminga, S. (2006), Estimation of the stoichiometry of volatile fatty acid production in the rumen of lactating cows, J. Theor. Biol. 238: 36-51.

Bayat, A. R., Kairenius, P., Stefánski, T., Leskinen, H., Comtet-Marre, S., Forano, E., Chaucheyras-Durand, F., Shingfield, K. J. (2015), Effect of camelina oil or live yeasts (Saccharomyces cerevisiae) on ruminal methane production, rumen fermentation, and milk fatty acid composition in lactating cows fed grass silage diets, J. Dairy Sci. 98: $3166-3181$.

Bayat, A. R., Ventto, L., Kairenius, P., Stefański, T., Leskinen, H., Tapio, I. Negussie, E., Vilkki, J. and Shingfield, K. J. (2017), Dietary forage to concentrate ratio and sunflower oil supplement alter rumen fermentation, ruminal methane emissions, and nutrient utilization in lactating cows, Transl. Anim. Sci. 1: 277-286.

Bayat, A. R., Tapio, I., Vilkki, J., Shingfield, K. J. and Leskinen, H. (2018), Plant oil supplements reduce methane emissions and improve milk fatty acid composition in dairy cows fed grass silage-based diets without affecting milk yield, J. Dairy Sci. 101: 1136-1151.

Beauchemin, K. A., Kreuzer, M., O'Mara, F. and McAllister, T. A. (2008), Nutritional management for enteric methane abatement: a review, Aust. J. Exp. Agric. 48: 21-27.

Benchaar, C., Pomar, C. and Chiquette, J. (2001), Evaluation of dietary strategies to reduce methane production in ruminants: a modelling approach, Can. J. Anim. Sci. 81: 563574. 
Benchaar, C., Hassanat, F., Gervais, R., Chouinard, P. Y., Petit, V. and Masse D. I. (2014), Methane production, digestion, ruminal fermentation, nitrogen balance, and milk production of cows fed corn silage- or barley silage-based diets, J. Dairy Sci. 97: 961974.

Benchaar, C., Hassanat, F., Martineau, R. and Gervais, R. (2015), Linseed oil supplementation to dairy cows fed diets based on red clover silage or corn silage: Effects on methane production, rumen fermentation, nutrient digestibility, $\mathrm{N}$ balance, and milk production, J. Dairy Sci. 98: 7993-8008.

Bernardes, T. F., Daniel, J. L. P., Adesogan, A. T., McAllister, T. A., Drouin, P., Nussio, L. G., Huhtanen, P., Tremblay, G. F., Bélanger, G. and Cai, Y. (2018), Silage review: Unique challenges of silages made in hot and cold regions, J. Dairy Sci. 101: 40014019.

Bertilsson, J., Åkerlind, M. and Eriksson, T. (2017), The effects of high-sugar ryegrass/red clover silage diets on intake, production, digestibility, and $\mathrm{N}$ utilization in dairy cows, as measured in vivo and predicted by the NorFor model, J. Dairy Sci. 100: 7990-8003.

Bougouin, A., Ferlay, A., Doreau, M. and Martin, C. (2018), Effects of carbohydrate type or bicarbonate addition to grass silage-based diets on enteric methane emissions and milk fatty acid composition in dairy cows, J. Dairy Sci. 101: 6085-6097.

Brask, M., Lund, P., Hellwing, A. L. F., Poulsen, M. and Weisbjerg, M. R. (2013a), Enteric methane production, digestibility and rumen fermentation in dairy cows fed different forages with and without rapeseed fat supplementation, Anim. Feed Sci. Technol. 184: 67-79.

Brask, M., Lund, P., Weisbjerg, M. R., Hellwing, A. L. F., Poulsen, M., Larsen, M. K. and Hvelplund, T. (2013b), Methane production and digestion of different physical forms of rapeseed as fat supplements in dairy cows, J. Dairy Sci. 96: 2356-2365. 
Broderick, G. A. (2003), Effects of varying dietary protein and energy levels on the production of lactating dairy cows, J. Dairy Sci. 86: 1370-1381.

Cabezas-Garcia, E. H., Krizsan, S. J., Shingfield, K. J. and Huhtanen, P. (2017), Effects of replacement of late-harvested grass silage and barley with early-harvested silage on milk production and methane emissions, J. Dairy Sci. 100: 5228-5240.

Castillo, A. R., Kebreab, E., Beever, D. E. and France, J. (2000), A review of efficiency of nitrogen utilisation in lactating dairy cows and its relationship with environmental pollution, J. Anim. Feed Sci. 9: 1-32.

Cherif, C., Hassanat, F., Claveau, S., Girard, J., Gervais, R. and Benchaar, C. (2018), Faba bean (Vicia faba) inclusion in dairy cow diets: Effect on nutrient digestion, rumen fermentation, nitrogen utilization, methane production, and milk performance, J. Dairy Sci. 101: 8916-8928.

De Boever, J. L., Goossens, K., Peiren, N., Swanckaert, J., Ampe, B., Reheul, D., Brabander, D. L, De Campeneere, S. and Vandaele, L. (2017), The effect of maize silage type on the performances and methane emission of dairy cattle, J. Anim. Physiol. Anim. Nutr. 101: e246-e256.

Dewhurst, R. J. (2013), Milk production from silage: comparison of grass, legume and maize silages and their mixtures, Agric. Food Sci. 22: 57-69.

Dijkstra, J., Oenema, O. and Bannink, A. (2011), Dietary strategies to reducing N excretion from cattle: implications for methane emissions, Curr. Opin. Env. Sust. 3: 414-422.

Dijkstra, J., Bannik, A., France, J., Kebreab, E. and Van Gastelen, S. (2018), Short communication: Antimethanogenic effects of 3-nitroxypropanol depend on supplementation dose, dietary fiber content, and cattle type, J. Dairy Sci. 101: 90419047. 
Doreau, M., Ferlay, A., Rochette, Y. and Martin, C. (2014), Effects of dehydrated lucerne and soya bean meal on milk production and composition, nutrient digestion, and methane and nitrogen losses in dairy cows receiving two different forages, Animal 8: 420-430.

Ellis, J. L., Hindrichsen, I. K., Klop, G., Kinley, R. D., Milora, N., Bannik, A. and Dijkstra, J. (2016), Effects of lactic acid bacteria silage inoculation on methane emission and productivity of Holstein Friesian dairy cattle, J. Dairy Sci. 99: 7159-7174.

Eugène, M., Massé, D., Chiquette, J. and Benchaar, C. (2008), Meta-analysis on the effects of lipid supplementation on methane production in lactating dairy cows, Can. J. Anim. Sci. 88: 331-337.

Ferlay, A., Doreau, M., Martin, C. and Chilliard, Y. (2013), Effects of incremental amounts of extruded linseed on the milk fatty acid composition of dairy cows receiving hay or corn silage, J. Dairy Sci. 96: 6577-6595.

Gidlund, H., Hetta, M., Krizsan, S. J., Lemosquet, S. and Huhtanen, P. (2015), Effects of soybean meal or canola meal on milk production and methane emissions in lactating dairy cows fed grass silage-based diets, J. Dairy Sci. 98: 8093-8106.

Gidlund, H., Hetta, M. and Huhtanen, P. (2017), Milk production and methane emissions from dairy cows fed a low or high proportion of red clover silage and an incremental level of rapeseed expeller, Liv. Sci. 197: 73-81.

Halmemies-Beauchet-Filleau, A., Kokkonen, T., Lampi, A. M., Toivonen, V., Shingfield, K. J. and Vanhatalo, A. (2011), Effect of plant oils and camelina expeller on milk fatty acid composition in lactating cows fed diets based on red clover silage, J. Dairy Sci. 94: 4413-4430.

Halmemies-Beauchet-Filleau, A., Shingfield, K. J., Simpura, I., Kokkonen, T., Jaakkola, S., Toivonen, V. and Vanhatalo, A. (2017), Effect of incremental amounts of camelina oil 
on milk fatty acid composition in lactating cows fed diets based on a mixture of grass and red clover silage and concentrates containing camelina expeller, J. Dairy Sci. 100: 305-324.

Halmemies-Beauchet-Filleau, A., Rinne, M., Lamminen, M., Mapato, C., Ampapon, T., Wanapat, M. and Vanhatalo, A. (2018), Alternative and novel feeds for ruminants: nutritive value, product quality and environmental aspects, Animal 12(s2): 295-309.

Halmemies-Beauchet-Filleau, A., Jaakkola, S., Kokkonen, T., Turpeinen, A., Givens, D. I., and Vanhatalo, A. (2019), Rapeseed lipids to decrease saturated fatty acids in milk and ruminal methane emissions of dairy cows. In Proc. 10th Nordic Feed Sci. Conf., pp 69-73.

Hammond, K. J., Jones, A. K., Humphries, D. J., Crompton, L. A. and Reynolds, C. K. (2016), Effects of diet forage source and neutral detergent fiber content on milk production of dairy cattle and methane emissions determined using GreenFeed and respiration chamber techniques, J. Dairy Sci. 99: 7904-7917.

Harrison, J., Huhtanen, P. and Collins, M. (2003), Perennial grasses, in Buxton, D. R., Muck, R. E. and Harrison, J. H. (eds.), Silage Science and Technology. American society of Agronomy, Crop Science Society of America and Soil Science of Society of America, Madison, WI, USA, pp. 635-747.

Hart, K. J., Huntington, J. A., Wilkinson, R. G., Bartram, C. G. and Sinclair, L. A. (2015), The influence of grass silage-to-maize silage ratio and concentrate composition on methane emissions, performance and milk composition of dairy cows, Animal 9: 983991.

Hassanat, F., Gervais, R., Julien, C., Massé, D. I., Lettat, A., Chouinard, P. Y., Petit, H. V. and Benchaar, C. (2013), Replacing alfalfa silage with corn silage in dairy cow diets: 
Effects on enteric methane production, ruminal fermentation, digestion, $\mathrm{N}$ balance, and milk production, J. Dairy Sci. 96: 4553-4567.

Hassanat, F., Gervais, R., Massé, D. I., Petit, H. V. and Benchaar, C. (2014), Methane production, nutrient digestion, ruminal fermentation, $\mathrm{N}$ balance, and milk production of cows fed timothy silage-or alfalfa silage-based diets, J. Dairy Sci. 97: 6463-6474.

Hassanat, F., Gervais, R. and Benchaar, C. (2017), Methane production, ruminal fermentation characteristics, nutrient digestibility, nitrogen excretion, and milk production of dairy cows fed conventional or brown midrib corn silage, J. Dairy Sci. 100: 2625-2636.

Hatew, B., Bannink, A., Van Laar, H., De Jonge, L. H. and Dijkstra, J. (2016), Increasing harvest maturity of whole-plant corn silage reduces methane emission of lactating dairy cows, J. Dairy Sci. 99: 354-368.

Havemose, M. S., Weisbjerg, M. R., Bredie, W. L. P., Poulsen, H. D. and Nielsen, J. H. (2006), Oxidative stability of milk influenced by fatty acids, antioxidants, and copper derived from feed, J. Dairy Sci. 89: 1970-1980.

Hollmann, M., Powers, W. J., Fogiel, A. C., Liesman, J. S., Bello, N. M. and Beede, D. K. (2012), Enteric methane emissions and lactational performance of Holstein cows fed different concentrations of coconut oil, J. Dairy Sci. 95: 2602-2615.

Hristov, A. N., Domitrovich, C., Wachter, A., Cassidy, T., Lee, C., Shingfield, K. J., Kairenius, P., Davis, J. and Brown, J. (2011), Effect of replacing solvent-extracted canola meal with high-oil traditional canola, high-oleic acid canola, or high-erucic acid rapeseed meals on rumen fermentation, digestibility, milk production, and milk fatty acid composition in lactating dairy cows, J. Dairy Sci. 94: 4057-4074. 
Hristov, A. N., Lee, C., Cassidy, T., Long, M., Heyler, K., Corl, B. and Forster, R. (2011), Effects of lauric and myristic acids on ruminal fermentation, production, and milk fatty acid composition in lactating dairy cows, J. Dairy Sci. 94: 382-395.

Hristov, A. N., Oh, J., Firkins, J. L., Dijkstra, J., Kebreab, E., Waghorn, G., Makkar, H. P. S., Adesogan, A. T., Yang, W., Lee, C., Gerber, P. J., Henderson, B. and Tricarico, J. M. (2013), Special topics-Mitigation of methane and nitrous oxide emissions from animal operations: I. A review of enteric methane mitigation options, J. Anim. Sci. 91: 50455069.

Huhtanen, P., Rinne, M. and Nousiainen, J. (2008), Evaluation of concentrate factors affecting silage intake of dairy cows: a development of the relative total diet intake index, Animal 2: 942-953.

Huhtanen, P. and Hristov, A. N. (2009), A meta-analysis of the effects of dietary protein concentration and degradability on milk protein yield and milk $\mathrm{N}$ efficiency in dairy cows, J. Dairy Sci. 92: 3222-3232.

Huhtanen, P., Hetta, M. and Swensson, C. (2011), Evaluation of canola meal as a protein supplement for dairy cows: A review and a meta-analysis, Can. J. Anim. Sci. 91: 529543.

Huhtanen, P., Jaakkola, S. and Nousiainen, J. (2013) An overview of silage research in Finland: from ensiling innovation to advances in dairy cow feeding, Agric. Food Sci. 22: $35-56$.

Huyen, N. T., Desrues, O., Alferink, S. J. J., Zandstra, T., Verstegen, W. A., Hendriks, W. H. and Pellikaan, W. F. (2016), Inclusion of sainfoin (Onobrychis viciifolia) silage in dairy cow rations affects nutrient digestibility, nitrogen utilization, energy balance, and methane emissions, J. Dairy Sci. 99: 3566-3577. 
1050 Jaakkola, S., Saarisalo, E. and Heikkilä, T. (2009), Formic acid treated whole crop barley and wheat silages in dairy cow diets: effects of crop maturity, proportion in the diet, and level and type of concentrate supplementation, Agric. Food Sci. 18: 234-256.

1053

1054

1055

1056

1057

1058

1059

1060

1061

1062

1063

1064

1065

1066

1067

1068

1069

1070

1071

1072

1073

Järvenranta, K., Kuoppala, K., Rinne, M. and Virkajärvi, P. (2016). Legumes in ruminant production systems in European cold climates - Limitations and opportunities, Legume perspectives Issue 12, April 2016, pp. 34-35.

Johnston, D. J., Theodoridou, K. and Ferris, C. P. (2019). The impact of field bean inclusion level in dairy cow diets on cow performance and nutrient utilisation, Liv. Sci. 220: 166172.

Jung, H. G., Mertens, D. R. and Phillips, R. L. (2011), Effect of reduced ferulate-mediated lignin/arabinoxylan cross-linking in corn silage on feed intake, digestibility, and milk production, J. Dairy Sci. 94: 5124-5137.

Kairenius, P., Toivonen, V., Ahvenjärvi, S., Vanhatalo, A., Givens, D. I. and Shingfield, K. J. (2009), Effects of rapeseed lipids in the diet on ruminal lipid metabolism and milk fatty acid composition in cows fed grass silage based diets, in Ruminant Physiology: Digestion, Metabolism and Effects of Nutrition on Reproduction and Welfare, Proc. XIth Intern. Symp. Rumin. Physiol. Wageningen Academic Pub., The Netherlands, pp 232233.

Khan, N. A., Yu, P., Ali, M., Cone, J. W. and Hendriks, W. H. (2015). Nutritive value of maize silage in relation to dairy cow performance and milk quality, J. Sci. Food Agric. 95: 238252.

Kliem, K. E., Humphries, D. J., Kirton, P., Givens, D. I. and Reynolds, C. K. (2019), Differential effects of oilseed supplements on methane production and milk fatty acid concentrations in dairy cows, Animal 13: 309-317. 
1074 Klop, G., Hatew, B., Bannink, A. and Dijkstra, J. (2016), Feeding nitrate and

1075

1076

1077

1078

1079

1080

1081

1082

1083

1084

1085

1086

1087

1088

1089

1090

1091

1092

1093

1094

1095

1096

1097 docosahexaenoic acid affects enteric methane production and milk fatty acid composition in lactating dairy cows, J. Dairy Sci. 99: 1161-1172.

Knapp, J. R., Laur, G. L., Vadas, P. A., Weiss, W. P. and Tricarico, J. M. (2014), Enteric methane in dairy cattle production: Quantifying the opportunities and impact of reducing emissions, J. Dairy Sci. 97: 3231-3261.

Krause, K. M. and Oetzel, G. R. (2006), Understanding and preventing subacute ruminal acidosis in dairy herds: A review, Anim. Feed Sci. Technol., 126: 215-236.

Kuoppala, K., Ahvenjärvi, S., Rinne, M. and Vanhatalo, A. (2009), Effects of feeding grass or red clover silage cut at two maturity stages in dairy cows. 2. Dry matter intake and cell wall digestion kinetics, J. Dairy Sci. 92: 5634-5644.

Kuoppala, K. (2010), Influence of harvesting strategy on nutrient supply and production of dairy cows consuming diets based on grass and red clover silage, Doctoral dissertation MTT Science 11, $49 \mathrm{p}$.

Lin, M. P., Sims, C. A., Staples, C. R. and O'Keefe, S. F. (1996), Flavor quality and texture of modified fatty acid high monoene, low saturate butter, Food Res. Int., 29: 367-371.

Livingstone, K. M., Humphries, D. J., Kirton, P., Kliem, K. E., Givens, D. I. and Reynolds, C. K. (2015), Effects of forage type and extruded linseed supplementation on methane production and milk fatty acid composition of lactating dairy cows, J. Dairy Sci. 98: 4000-4011.

Lock, A. L. and Shingfield, K. J. (2004), Optimizing milk composition, in Kebreab, E., Mills, J., Beever, D.E. (eds.), Dairying -Using Science to Meet Consumers Needs, Br. Soc. Anim. Sci. Publ. 29. Nottingham University Press, Loughborough, United Kingdom, pp 107-188. 
Maia, M. R., Chaudhary, L. C., Figueres, L. and Wallace, R. J. (2007), Metabolism of polyunsaturated fatty acids and their toxicity to the microflora of the rumen, Antonie Van Leeuwenhoek, 91: 303-314.

Martin, C., Rouel, J., Jouany, J. P., Doreau, M. and Chilliard, Y. (2008), Methane output and diet digestibility in response to feeding dairy cows crude linseed, extruded linseed, or linseed oil, J. Anim. Sci. 86: 2642-2650.

Martin, C., Morgavi, D. P. and Doreau, M. (2010), Methane mitigation in ruminants: from microbe to the farm scale, Animal 4: 351-365.

Martin, C., Ferlay, A., Mosoni, P., Rochette, Y., Chilliard, Y. and Doreau, M. (2016), Increasing linseed supply in dairy cow diets based on hay or corn silage: Effect on enteric methane emission, rumen microbial fermentation, and digestion, J. Dairy Sci. 99: 3445-3456.

Martineau, R., Ouellet, D. R. and Lapierre, H. (2013), Feeding canola meal to dairy cows: A meta-analysis on lactational responses, J. Dairy Sci. 96: 1701-1714.

Martinez-Fernandez. G., Duval, S., Kinderman, M., Schirra, H. J., Denman, S. E. and McSweeney C. S. (2018), 3-NOP vs. halogenated compound: methane production, ruminal fermentation and microbial community response in forage fed cattle, Front. Microbiol. 9: 1-13.

Merry, R. J., Lee, M. R. F., Davies, D. R., Dewhurst, R. J., Moorby, J. M., Scollan, N. D. and Theodorou, M. K. (2006), Effects of high-sugar ryegrass silage and mixtures with red clover silage on ruminant digestion. 1. In vitro and in vivo studies of nitrogen utilization, J. Anim. Sci. 84: 3049-3060.

Moate, P. J., Williams, S. R. O., Hannah, M. C., Eckard, R. J., Auldist, M. J., Ribaux, B. E., Jacobs, J. L. and Wales, W. J. (2013), Effects of feeding algal meal high in 
docosahexaenoic acid on feed intake, milk production, and methane emissions in dairy cows, J. Dairy Sci. 96: 3177-3188.

Moss, A. R., Jouany, J.-P. and Newbold, J. (2000). Methane production by ruminants: its contribution to global warming. Ann. Zootech. 49:231-253.

Moorby, J. M., Evans, R. T., Scollan, N. D., MacRae, J. C. and Theodorou, M. K. (2006), Increased concentration of water-soluble carbohydrate in perennial ryegrass (Lolium perenne L.). Evaluation in dairy cows in early lactation, Grass For. Sci. 61: 52-59.

Muck, R. E., Nadeau, E. M. G., McAllister, T. A., Contreras-Govea, F. E., Santos, M. C. and Kung, L. (2018), Silage review: Recent advances and future uses of silage additives, J. Dairy Sci. 101: 3980-4000.

Niu, M., Appuhamy, J. A. D. R. N., Leytem, A. B., Dungan, R. S. and Kebreab, E. (2016), Effect of dietary crude protein and forage contents on enteric methane emissions and nitrogen excretion from dairy cows simultaneously, Anim. Prod. Sci. 56: 312-321.

Odongo, N. E., Or-Rashid, M. M., Kebreab, E., France, J. and McBride, B. W. (2007), Effect of supplementing myristic acid in dairy cow rations on ruminal methanogenesis and fatty acid profile in milk, J. Dairy Sci. 90: 1851-1858.

Olijhoek, D. W., Løvendahl, P., Lassen, J., Hellwing, A. L. F., Höglund, J. K., Weisbjerg, M. R., Noel, S. J., McLean, F., Hojberg, O. and Lund, P. (2018), Methane production, rumen fermentation, and diet digestibility of Holstein and Jersey dairy cows being divergent in residual feed intake and fed at 2 forage-to-concentrate ratios, J. Dairy Sci. 101: $9926-9940$.

Pang, D., Yan, T., Trevisi, E. and Krizsan, S. J. (2018), Effect of grain-or by-product-based concentrate fed with early-or late-harvested first-cut grass silage on dairy cow performance, J. Dairy Sci. 101: 7133-7145. 
1146

1147

1148

1149

1150

1151

1152

1153

1154

1155

1156

1157

1158

1159

1160

1161

1162

1163

1164

1165

1166

1167

1168

Phelan P., Moloney, A. P., McGeough, E. J., Humphreys, J., Bertilsson, J., O'Riordan, E. G. and O'Kiely, P. (2015), Forage legumes for grazing and conserving in ruminant production systems, Crit. Rev. Plant Sci. 34: 281-326.

Piccioli-Cappelli, F., Loor, J. J., Seal, C. J., Minuti, A. and Trevisi, E. (2014), Effect of dietary starch level and high rumen-undegradable protein on endocrine-metabolic status, milk yield, and milk composition in dairy cows during early and late lactation, J. Dairy Sci. 97: 7788-7803.

Pirondini, M., Colombini, S., Mele, M., Malagutti, L., Rapetti, L., Galassi, G. and Crovetto, G. M. (2015), Effect of dietary starch concentration and fish oil supplementation on milk yield and composition, diet digestibility, and methane emissions in lactating dairy cows, J. Dairy Sci. 98: 357-372.

Puhakka, L., Jaakkola, S., Simpura, I., Kokkonen, T. and Vanhatalo, A. (2016), Effects of replacing rapeseed meal with fava bean at 2 concentrate crude protein levels on feed intake, nutrient digestion, and milk production in cows fed grass silage-based diets, $\mathrm{J}$. Dairy Sci. 99: 7993-8006.

Ramin, M., Höjer, A. and Hetta, M. (2017), The effects of legume seeds on the lactation performance of dairy cows fed grass silage-based diets, Agr. Food Sci. 26: 129-137.

Reynolds, C. K., Crompton, L. A., Mills, J. A. N., Humphries, D. J., Kirton, P., Relling, A. E., Misselbrook, T. H., Chadwick, D. R. and Givens, D. I. (2010), Effects of diet protein level and forage source on energy and nitrogen balance and methane and nitrogen excretion in lactating dairy cows, in G. M. Crovetto (eds.), Energy and protein metabolism and nutrition, Proc. 3rd EAAP Int. Symp. Energy Prot. Met. Nutr., Wageningen Academic Pub., The Netherlands, pp 463-464. 
1169 Rinne, M., Jaakkola, S. and Huhtanen, P. (1997), Grass maturity effects on cattle fed silage-

1170

1171

1172

1173

1174

1175

1176

1177

1178

1179

1180

1181

1182

1183

1184

1185

1186

1187

1188

1189

1190

1191

1192

based diets. 1. Organic matter digestion, rumen fermentation and nitrogen utilization, Anim. Feed Sci. Technol. 67: 1-17.

Rinne, M. 2000. Influence of the timing of the harvest of primary grass growth on herbage quality and subsequent digestion and performance in the ruminant animal, Academic dissertation. University of Helsinki. Department of Animal Science Publications 54. Helsinki University Press. Helsinki. 42 p.

Sauer, F. D., Fellner, V., Kinsman, R., Kramer, J. K. G., Jackson, H. A., Lee, A. J. and Chen, S. (1998), Methane output and lactation response in Holstein cattle with monensin or unsaturated fat added to the diet, J. Anim. Sci. 76: 906-914.

Shingfield, K. J., Bernard, L., Leroux, C. and Chilliard, Y. (2010), Role of trans fatty acids in the nutritional regulation of mammary lipogenesis in ruminants, Animal 4: 1140-1166.

Shingfield, K. J., Bonnet, M. and Scollan, N. D. (2013), Recent developments in altering the fatty acid composition of ruminant-derived foods, Animal 7(s1): 132-162.

Sjaunja, L. O., Bævre, L., Junkkarinen, L., Pedersen, J. and Setälä, J. (1991), A Nordic proposal for an energy corrected milk (ECM) formula, in Proceedings of the 27th Biennial Session of the International Committee for Animal Recording (ICAR), Paris, France. Wageningen Academic, the Netherlands, pp 156-157.

Staerfl, S. M., Amelchanka, S. L., Kälber, T., Soliva, C-.R., Kreuzer, M. and Zeitz, J. O. (2012), Effect of feeding dried high-sugar ryegrass ('AberMagic') on methane and urinary nitrogen emission of primiparous cows, Liv. Sci. 150: 203-301.

Van Dorland, H. A., Wettstein, H. R., Leuenberger, H. and Kreuzer, M. (2007), Effect of supplementation of fresh and ensiled clovers to ryegrass on nitrogen loss and methane emission of dairy cows, Liv. Sci. 111: 57-69. 
1193

1194

1195

1196

1197

1198

1199

1200

1201

1202

1203

1204

1205

1206

1207

1208

1209

1210

1211

1212

1213

1214

1215

1216

1217

Van Gastelen, S., Antunes-Fernandes, E. C., Hettinga, K. A., Klop, G., Alferink, S. J. J., Hendriks, W. H. and Dijkstra, J. (2015), Enteric methane production, rumen volatile fatty acid concentrations, and milk fatty acid composition in lactating Holstein-Friesian cows fed grass silage-or corn silage-based diets, J. Dairy Sci. 98: 1915-1927.

Van Gastelen, S., Dijkstra, J. and Bannink, A. (2019), Are dietary strategies to mitigate enteric methane emission equally effective across dairy cattle, beef cattle, and sheep?, J. Dairy Sci. 102: 6109-6130.

Vanhatalo, A. and Jaakkola, S. (2016), Intake and performance with temperate forage legume-based ruminant production systems. Legume perspectives, Issue 12, April 2016, pp 17-19.

Van Kessel, J. A. S. and Russell, J. B. (1996), The effect of pH on ruminal methanogenesis, FEMS Microb. Ecol. 20: 205-210.

Van Middelaar, C. E., Berentsen, P. B. M., Dijkstra, J. and De Boer, I. J. M. (2013), Evaluation of a feeding strategy to reduce greenhouse gas emissions from dairy farming: The level of analysis matters, Agric. Syst. 121: 9-22.

Ventto, L., Leskinen, H., Kairenius, P., Stefański, T., Bayat, A. R., Vilkki, J. and Shingfield, K. J. (2017), Diet-induced milk fat depression is associated with alterations in ruminal biohydrogenation pathways and formation of novel fatty acid intermediates in lactating cows, Br. J. Nutr. 117: 364-376.

Warner, D., Hatew, B., Podesta, S. C., Klop, G., Van Gastelen, S., Van Laar, H., Dijkstra, J. and Bannink, A. (2016), Effects of nitrogen fertilisation rate and maturity of grass silage on methane emission by lactating dairy cows, Animal 10: $34-43$.

Warner, D., Bannink, A., Hatew, B., Van Laar, H. and Dijkstra, J. (2017), Effects of grass silage quality and level of feed intake on enteric methane production in lactating dairy cows, J. Anim. Sci. 95: 3687-3699. 
1218 Wilkinson, J.M. and Rinne, M. (2018), Highlights of progress in silage conservation and 1219 future perspectives, Grass For. Sci. 73: 40-52. 
Table 1. The effects of substituting basal forage with forage differing in plant maturity, ensiling method or plant species on dairy cow performance

\begin{tabular}{|c|c|c|c|c|c|c|c|c|c|c|c|c|}
\hline \multirow[b]{2}{*}{ Basal forage $^{2}$} & \multirow[b]{2}{*}{$\begin{array}{c}\text { Plant species / } \\
\text { Variety }\end{array}$} & \multirow[b]{2}{*}{ Substituting forage ${ }^{2}$} & \multirow[b]{2}{*}{$\mathrm{F}: \mathrm{C}^{3}$} & \multicolumn{5}{|c|}{ Change in $\%$ relative to control ${ }^{1}$} & \multicolumn{3}{|c|}{$\begin{array}{c}\mathrm{CH}_{4} \text { emission intensity, } \\
\mathrm{g} \mathrm{CH}_{4} / \mathrm{kg} \text { ECM }\end{array}$} & \multirow{2}{*}{ Reference } \\
\hline & & & & DMI & ECM & $\mathrm{FE}$ & NUE & $\begin{array}{l}\text { Rumen } \\
\text { C2 / C3 }\end{array}$ & Control & Test & $\begin{array}{l}\text { Change } \\
\text { in } \%\end{array}$ & \\
\hline \multicolumn{13}{|l|}{ Grass silage } \\
\hline Late cut & Ryegrass ${ }^{4}$ & Early cut, Primary growth & $65: 35$ & 9 & 11 & 2 & -7 & -2 & 16.9 & 14.7 & -13 & Brask et al. 2013a \\
\hline Late cut & Timothy & Early cut, Primary growth & $60: 40$ & 10 & 13 & 3 & -17 & NR & 14.0 & 13.1 & -7 & Pang et al. 2018 \\
\hline Late cut, Low N & Ryegrass:Timothy & Early cut, Sec. growth & $80: 20$ & 6 & 32 & 25 & -13 & 18 & 15.9 & 12.5 & -21 & Warner et al. 2016 \\
\hline Late cut, High N & & Early cut, Sec. growth & & 20 & 34 & 12 & -8 & -1 & 16.3 & 13.1 & -20 & \\
\hline Low $\mathrm{N}$ & & High N & & -4 & -2 & 2 & -19 & -4 & 15.2 & 14.9 & -2 & \\
\hline Late cut ${ }^{5}$ & Ryegrass:Timothy & Very early cut (leafy) & $80: 20$ & 9 & 12 & 6 & -35 & NR & 14.0 & 11.2 & -20 & Warner et al. 2017 \\
\hline Late cut 6 & & Primary growth 7 & & 4 & 11 & 8 & -35 & NR & 12.9 & 10.2 & -21 & \\
\hline No additive & Ryegrass:Timothy & Inoculated grass & $75: 25$ & 3 & 2 & -1 & 4 & NR & 16.0 & 16.0 & 0 & Ellis et al. 2016 \\
\hline Low sugar & Ryegrass & High sugar & $100: 0$ & -8 & -15 & -8 & 46 & NR & 16.5 & 17.2 & 4 & Staerfl et al. 2012 \\
\hline \multicolumn{13}{|l|}{ Legume silage } \\
\hline Grass & Timothy & Lucerne & $60: 40$ & 9 & -2 & -10 & -15 & -1 & 12.8 & 13.4 & 5 & Hassanat et al. 2014 \\
\hline Red clover:grass 30:70 & NR:Timothy & Red clover:grass 70:30 & $60: 40$ & -1 & 0 & 1 & -10 & NR & 15.2 & 15.5 & 5 & Gidlund et al. 2017 \\
\hline $\begin{array}{l}\text { Grass:sainfoin:maize } \\
86: 0: 14\end{array}$ & NR & $\begin{array}{c}\text { Grass:sainfoin:maize } \\
42: 42: 16\end{array}$ & $70: 30$ & 5 & 7 & 2 & -5 & NR & 15.0 & 13.9 & -7 & Huyen et al. 2016 \\
\hline \multicolumn{13}{|l|}{ Maize silage } \\
\hline Early cut maize & LG30218 & Late cut maize & $80: 20$ & 0 & 0 & 0 & -3 & 13 & 12.8 & 11.9 & -7 & Hatew et al. 2016 \\
\hline Conventional maize & NR & Brown midrib maize & $65: 35$ & 6 & 8 & 1 & 5 & -4 & 14.0 & 12.6 & -10 & Hassanat et al. 2017 \\
\hline Barley & Cut at soft dough & Maize, two-thirds at milkline & $60: 40$ & 20 & 15 & -4 & 6 & -13 & 15.0 & 14.9 & -1 & Benchaar et al. 2014 \\
\hline Grass & NR & Maize & $80: 20$ & 8 & 7 & -1 & 18 & 6 & 16.6 & 15.0 & -10 & Van Gastelen et al. 2015 \\
\hline Early cut grass & Ryegrass 4 & Maize & $65: 35$ & -1 & 0 & 2 & 24 & -22 & 14.7 & 13.8 & -6 & Brask et al. 2013a \\
\hline Late cut grass & & & & 7 & 11 & 4 & 15 & -23 & 16.9 & 13.8 & -19 & \\
\hline Grass:maize 75:25 & NR & Grass:maize 25:75 & $50: 50$ & 11 & 5 & -5 & -7 & NR & 15.0 & 14.3 & -5 & Reynolds et al. 2010 \\
\hline Grass:maize $75: 25^{8}$ & Third cut ryegrass & Grass:maize 25:75 & $50: 50$ & 28 & 9 & -15 & -10 & NR & 16.3 & 14.2 & -13 & Hammond et al. 2016 \\
\hline Same diets as above ${ }^{9}$ & & & & 19 & 24 & 4 & 15 & NR & 16.9 & 16.2 & -4 & \\
\hline
\end{tabular}




\begin{tabular}{|c|c|c|c|c|c|c|c|c|c|c|c|c|}
\hline Grass:maize 75:25 & NR & Grass:maize 25:75 & $50: 50$ & 7 & -2 & -8 & 1 & NR & 12.9 & 12.0 & 7 & Livingstone et al. 2015 \\
\hline Grass & $\begin{array}{c}\text { Ryegrass: } \\
\text { cocksfoot:fescue }\end{array}$ & $\begin{array}{c}\text { Maize } \\
\text { at vitreous stage }\end{array}$ & $45: 55$ & 0 & -2 & -2 & 6 & -5 & 14.9 & 13.4 & -10 & Doreau et al. 2014 \\
\hline Red clover & NR & Maize & $60: 40$ & 0 & 2 & 2 & 7 & -16 & 14.6 & 14.1 & -4 & Benchaar et al. 2015 \\
\hline Lucerne & NR & Maize & $60: 40$ & 5 & -1 & -6 & 14 & -26 & 13.9 & 14.4 & 3 & Hassanat et al. 2013 \\
\hline Lucerne:maize 80:20 & NR & Lucerne:maize 20:80 & $55: 45$ & -1 & 0 & 1 & 15 & -18 & 17.8 & 18.1 & 2 & Arnd et al. 2015 \\
\hline
\end{tabular}

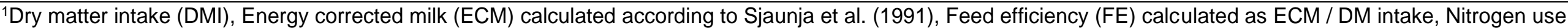

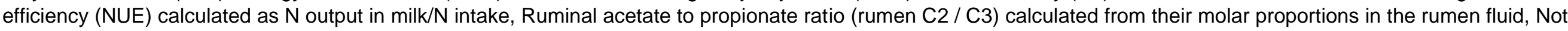

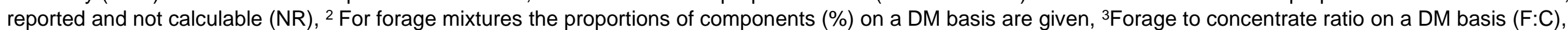

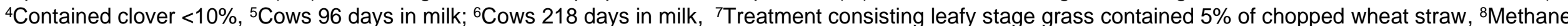
measured with GreenFeed, ${ }^{9}$ Methane measured with respiratory chamber 
Table 2. The effects of supplemental lipid on dairy cow performance

\begin{tabular}{|c|c|c|c|c|c|c|c|c|c|c|c|c|c|}
\hline \multirow[b]{2}{*}{ Lipid source } & \multirow[b]{2}{*}{ Form } & \multirow[b]{2}{*}{$\begin{array}{l}\text { Lipid } \\
\text { dosage } \\
\text { in diet } \\
\text { DM }\end{array}$} & \multirow[b]{2}{*}{$\begin{array}{l}\text { Basal forage } \\
\text { component }^{2}\end{array}$} & \multirow[b]{2}{*}{$\mathrm{F}: \mathrm{C}^{3}$} & \multicolumn{5}{|c|}{$\begin{array}{l}\text { Change in \% relative to } \\
\text { unsupplemented control diet }{ }^{1}\end{array}$} & \multicolumn{3}{|c|}{$\begin{array}{l}\mathrm{CH}_{4} \text { emission intensity, } \\
\mathrm{g} \mathrm{CH}_{4} \text { per kg ECM }\end{array}$} & \multirow{2}{*}{ Reference } \\
\hline & & & & & DMI & ECM & $\mathrm{FE}$ & NUE & $\begin{array}{l}\text { Rumen } \\
\text { C2 / C3 }\end{array}$ & $\begin{array}{l}\text { Control } \\
\text { diet }\end{array}$ & $\begin{array}{l}\text { Lipid } \\
\text { diet }\end{array}$ & $\begin{array}{c}\text { Change } \\
\text { in } \%\end{array}$ & \\
\hline \multicolumn{14}{|c|}{ Medium chain saturated fatty acids } \\
\hline Myristic acid & oil & $5 \%$ & $\begin{array}{c}\text { Maize silage:grass } \\
\text { haylage:hay 55:35:10 }\end{array}$ & $60: 40$ & -7 & -10 & -4 & -1 & NR & 28.4 & 20.4 & -28 & Odongo et al. 2007 \\
\hline Myristic acid & methyl ester & $5 \%$ & Grass silage & $60: 40$ & -31 & -20 & 17 & 2 & -6 & 22.7 & 18.8 & -17 & Bayat et al. 2018 \\
\hline Coconut & oil & $\begin{array}{l}1.3 \% \\
2.7 \% \\
3.3 \% \\
\end{array}$ & $\begin{array}{l}\text { Maize:lucerne:grass } \\
\text { silages 75:15:10 }\end{array}$ & $50: 50$ & $\begin{array}{r}-7 \\
-22 \\
-29 \\
\end{array}$ & $\begin{array}{r}4 \\
-18 \\
-24 \\
\end{array}$ & $\begin{array}{r}12 \\
4 \\
8 \\
\end{array}$ & $\begin{array}{r}9 \\
11 \\
22 \\
\end{array}$ & $\begin{array}{l}\text { NR } \\
\text { NR } \\
\text { NR } \\
\end{array}$ & $\begin{array}{l}13.9 \\
13.9 \\
13.9 \\
\end{array}$ & $\begin{array}{r}12.9 \\
14.4 \\
9.9 \\
\end{array}$ & $\begin{array}{r}-7 \\
3 \\
-29 \\
\end{array}$ & Hollmann et al. 2012 \\
\hline \multicolumn{14}{|c|}{ Monounsaturated fatty acids } \\
\hline Rapeseed & $\begin{array}{l}\text { cake } \\
\text { crushed } \\
\text { oil }\end{array}$ & $2-3 \%$ & $\begin{array}{c}\text { Grass:maize silages } \\
55: 45\end{array}$ & $50: 50$ & $\begin{array}{r}3 \\
-2 \\
-14\end{array}$ & $\begin{array}{r}11 \\
-8 \\
4\end{array}$ & $\begin{array}{r}8 \\
-6 \\
21\end{array}$ & $\begin{array}{l}8 \\
4 \\
6\end{array}$ & $\begin{array}{r}-1 \\
-1 \\
7\end{array}$ & $\begin{array}{l}14.6 \\
14.6 \\
14.6\end{array}$ & $\begin{array}{l}13.6 \\
12.1 \\
12.0\end{array}$ & $\begin{array}{r}-7 \\
-17 \\
-18\end{array}$ & Brask et al. 2013b \\
\hline Rapeseed & crushed & $3 \%$ & $\begin{array}{l}\quad \text { Maize silage } \\
\text { Early grass silage } \\
\text { Late grass silage }^{4}\end{array}$ & $65: 35$ & $\begin{array}{r}-5 \\
-2 \\
1\end{array}$ & $\begin{array}{r}-10 \\
-1 \\
3\end{array}$ & $\begin{array}{r}-6 \\
1 \\
3\end{array}$ & $\begin{array}{l}7 \\
0 \\
3\end{array}$ & $\begin{array}{r}-2 \\
-1 \\
1\end{array}$ & $\begin{array}{l}13.7 \\
15.6 \\
17.8\end{array}$ & $\begin{array}{l}14.0 \\
13.9 \\
16.1\end{array}$ & $\begin{array}{r}3 \\
-11 \\
-10\end{array}$ & Brask et al. $2013 a$ \\
\hline Rapeseed & crushed & $2 \%$ & $\begin{array}{c}\text { Maize:grass silages } \\
75: 25\end{array}$ & $50: 50$ & 2 & 4 & 1 & 4 & NR & 14.7 & 14.2 & -3 & Kliem et al. 2019 \\
\hline Rapeseed & oil & $5 \%$ & Grass silage & $60: 40$ & -12 & 3 & 17 & 11 & 3 & 22.7 & 17.5 & -23 & Bayat et al. 2018 \\
\hline \multicolumn{14}{|c|}{ Polyunsaturated fatty acids } \\
\hline Safflower & oil & $5 \%$ & Grass silage & $60: 40$ & -6 & 2 & 9 & 6 & 0 & 22.7 & 17.5 & -23 & Bayat et al. 2018 \\
\hline Soybean & oil & $3.5 \%$ & $\begin{array}{c}\text { Maize silage:lucerne } \\
\text { haylage:hay } 45: 40: 15\end{array}$ & $65: 35$ & -3 & 0 & 4 & NR & NR & 18.3 & 18.2 & 0 & Sauer et al. 1998 \\
\hline Sunflower & oil & $5 \%$ & Grass silage & $\begin{array}{l}65: 35 \\
35: 65\end{array}$ & $\begin{array}{r}-2 \\
-11\end{array}$ & $\begin{array}{r}-2 \\
-16\end{array}$ & $\begin{array}{r}0 \\
-6\end{array}$ & $\begin{array}{l}-6 \\
13\end{array}$ & $\begin{array}{r}-5 \\
3\end{array}$ & $\begin{array}{l}18.9 \\
14.2\end{array}$ & $\begin{array}{l}14.5 \\
14.5\end{array}$ & $\begin{array}{r}-23 \\
2\end{array}$ & Bayat et al. 2017 \\
\hline
\end{tabular}




\begin{tabular}{|c|c|c|c|c|c|c|c|c|c|c|c|c|c|}
\hline Linseed & extruded & $\begin{array}{l}1.8 \% \\
3.6 \% \\
5.4 \% \\
1.8 \% \\
3.6 \% \\
5.4 \%\end{array}$ & $\begin{array}{l}\text { Maize silage:grass hay } \\
\qquad 90: 10 \\
\text { Grass hay }\end{array}$ & $60: 40$ & $\begin{array}{r}-2 \\
-5 \\
-11 \\
-9 \\
-4 \\
-4\end{array}$ & $\begin{array}{r}-15 \\
-16 \\
-5 \\
-4 \\
5 \\
-3\end{array}$ & $\begin{array}{r}-14 \\
-12 \\
7 \\
6 \\
10 \\
1\end{array}$ & $\begin{array}{r}-2 \\
-3 \\
12 \\
5 \\
8 \\
12\end{array}$ & $\begin{array}{r}-9 \\
-14 \\
-27 \\
-6 \\
-6 \\
-12\end{array}$ & $\begin{array}{l}15.4 \\
15.4 \\
15.4 \\
19.8 \\
19.8 \\
19.8\end{array}$ & $\begin{array}{r}17.1 \\
15.9 \\
9.4 \\
17.4 \\
15.3 \\
12.2\end{array}$ & $\begin{array}{r}11 \\
4 \\
-39 \\
-12 \\
-23 \\
-39\end{array}$ & $\begin{array}{l}\text { Ferlay et al. } 2013 \\
\text { Martin et al. } 2016\end{array}$ \\
\hline $\begin{array}{l}\text { Linseed } \\
\text { Linseed and } \\
\text { palm mix }\end{array}$ & $\begin{array}{l}\text { extruded } \\
\text { Ca-salts of } \\
\text { oil mix }\end{array}$ & $\begin{array}{l}2 \% \\
2 \%\end{array}$ & $\begin{array}{c}\text { Maize:grass silages } \\
75: 25\end{array}$ & $\begin{array}{l}50: 50 \\
50: 50\end{array}$ & $\begin{array}{r}0 \\
-2\end{array}$ & $\begin{array}{l}2 \\
3\end{array}$ & $\begin{array}{l}2 \\
6\end{array}$ & $\begin{array}{l}4 \\
1\end{array}$ & $\begin{array}{l}\text { NR } \\
\text { NR }\end{array}$ & $\begin{array}{l}14.7 \\
14.7\end{array}$ & $\begin{array}{l}13.4 \\
12.8\end{array}$ & $\begin{array}{r}-9 \\
-13\end{array}$ & Kliem et al. 2019 \\
\hline Linseed & oil & $4 \%$ & $\begin{array}{c}\text { Maize silage } \\
\text { Red clover silage }\end{array}$ & $\begin{array}{l}60: 40 \\
60: 40\end{array}$ & $\begin{array}{l}-9 \\
-2\end{array}$ & $\begin{array}{r}-14 \\
2\end{array}$ & $\begin{array}{r}-6 \\
4\end{array}$ & $\begin{array}{l}1 \\
5\end{array}$ & $\begin{array}{r}-22 \\
-4\end{array}$ & $\begin{array}{l}14.1 \\
14.6\end{array}$ & $\begin{array}{l}12.1 \\
13.0\end{array}$ & $\begin{array}{l}-14 \\
-11\end{array}$ & Benchaar et al 2015 \\
\hline Linseed & oil & $5 \%$ & Grass silage & $60: 40$ & -8 & 3 & 12 & 5 & 2 & 22.7 & 17.5 & -23 & Bayat et al. 2018 \\
\hline Fish & oil & $\begin{array}{l}0.8 \% \\
0.8 \%\end{array}$ & $\begin{array}{l}\text { Maize silage:lucerne hay: } \\
\text { grass hay } 55: 25: 20\end{array}$ & $\begin{array}{l}52: 48^{5} \\
52: 48^{6}\end{array}$ & $\begin{array}{r}4 \\
-2\end{array}$ & $\begin{array}{r}8 \\
-3\end{array}$ & $\begin{array}{r}4 \\
-1\end{array}$ & $\begin{array}{r}-7 \\
1\end{array}$ & $\begin{array}{r}-1 \\
0\end{array}$ & $\begin{array}{l}13.5 \\
12.4\end{array}$ & $\begin{array}{l}12.6 \\
13.2\end{array}$ & $\begin{array}{r}-7 \\
6\end{array}$ & Pirondini et al. 2015 \\
\hline $\begin{array}{l}\text { Algae } \\
\text { rich in } 22: 6 n-3\end{array}$ & meal & $\begin{array}{c}0.3 \% \\
0.6 \% \\
1 \%\end{array}$ & Lucerne hay & $74: 26$ & $\begin{array}{r}0 \\
-6 \\
-11\end{array}$ & $\begin{array}{r}-6 \\
-14 \\
-15\end{array}$ & $\begin{array}{l}-6 \\
-8 \\
-5\end{array}$ & $\begin{array}{l}3 \\
5 \\
0\end{array}$ & $\begin{array}{r}2 \\
-1 \\
4\end{array}$ & $\begin{array}{l}21.8 \\
21.8 \\
21.8\end{array}$ & $\begin{array}{l}23.9 \\
25.7 \\
24.1\end{array}$ & $\begin{array}{l}10 \\
18 \\
11\end{array}$ & Moate et al. 2015 \\
\hline $\begin{array}{l}\text { Algae } \\
\text { rich in 22:6n-3 }\end{array}$ & meal & $0.3 \% 7$ & $\begin{array}{c}\text { Maize:grass silages } \\
70: 30 \\
\end{array}$ & $70: 30$ & 0 & -12 & -12 & 0 & NR & 9.5 & 11.1 & 16 & Klop et al. 2016 \\
\hline
\end{tabular}

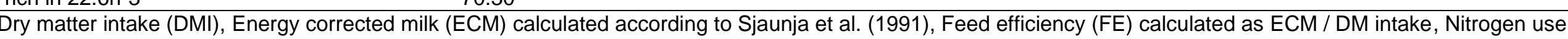

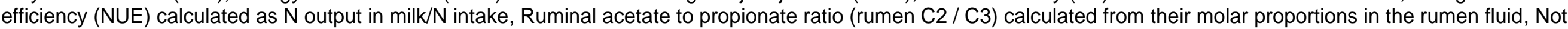

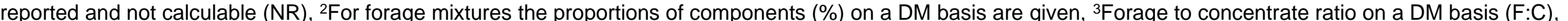

${ }^{4}$ Contains $<10 \%$ in DM clover, ${ }^{5}$ Concentrate low in starch, ${ }^{6}$ Concentrate high in starch, ${ }^{7}$ Supplemental DHA \% in diet DM 
Table 3. The effects of concentrate level and diet starch content on dairy cow performance

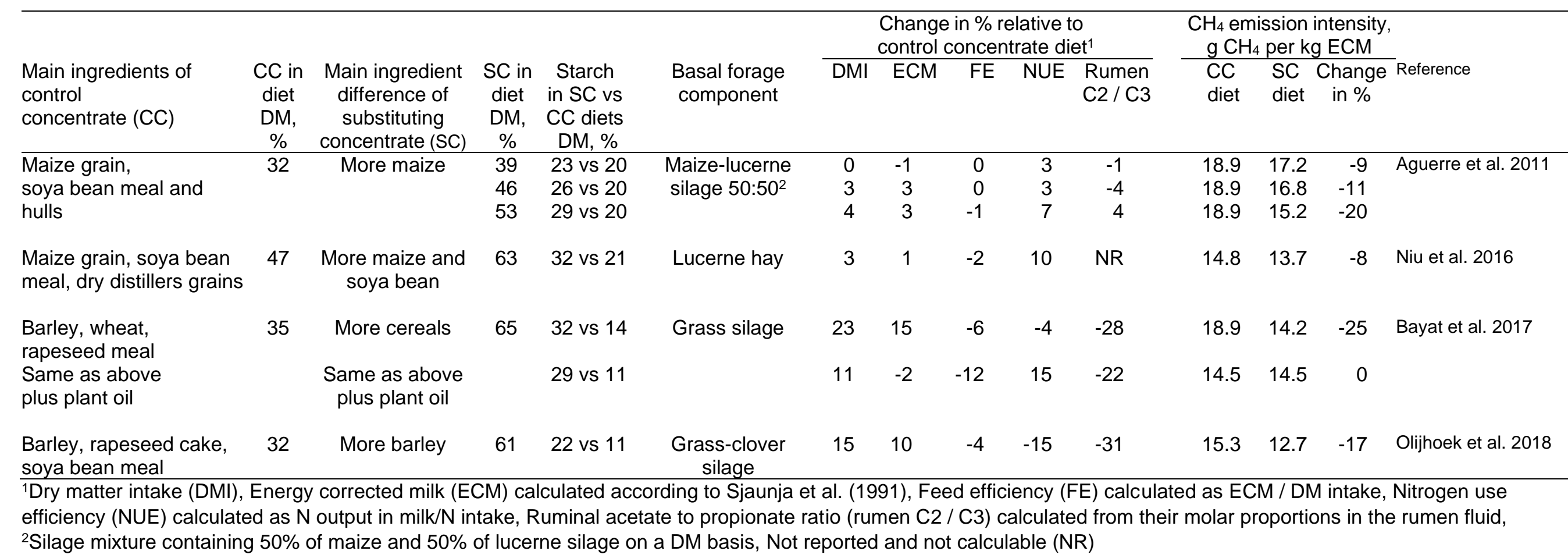


Table 4. The effects of concentrate carbohydrate and protein source and protein level on dairy cow performance

\begin{tabular}{|c|c|c|c|c|c|c|c|c|c|c|c|c|c|}
\hline \multirow[b]{2}{*}{$\begin{array}{l}\text { Control } \\
\text { concentrate (CC) } \\
\text { main ingredients }\end{array}$} & \multirow[b]{2}{*}{$\begin{array}{l}\text { Difference in substituting } \\
\text { concentrate (SC) }\end{array}$} & \multirow[b]{2}{*}{$\begin{array}{l}\text { In SC vs } \\
\text { CC diet } \\
\text { DM, \% }\end{array}$} & \multirow[b]{2}{*}{$\begin{array}{l}\text { Basal forage } \\
\text { component }^{2}\end{array}$} & \multirow[b]{2}{*}{$F: C^{3}$} & \multicolumn{5}{|c|}{$\begin{array}{l}\text { Change in } \% \text { relative to } \\
\text { control concentrate diet }{ }^{1}\end{array}$} & \multicolumn{3}{|c|}{$\begin{array}{l}\mathrm{CH}_{4} \text { emission intensity, } \\
\mathrm{g} \mathrm{CH}_{4} \text { per kg ECM }\end{array}$} & \multirow{2}{*}{ Reference } \\
\hline & & & & & DMI & ECM & FE & NUE & $\begin{array}{l}\text { Rumen } \\
\text { C2 / C3 }\end{array}$ & $\begin{array}{l}\mathrm{CC} \\
\text { diet }\end{array}$ & $\begin{array}{l}\text { SC } \\
\text { diet }\end{array}$ & $\begin{array}{l}\text { Change } \\
\text { in } \%\end{array}$ & \\
\hline $\begin{array}{l}\text { Carbohydrate source } \\
\text { Citrus and sugar beet } \\
\text { pulps, soya bean hulls, } \\
\text { palm kernel extract }\end{array}$ & Wheat, wheatfeed & $\begin{array}{l}\text { Starch } \\
15 \text { vs } 10 \\
19 \text { vs } 14\end{array}$ & $\begin{array}{l}\text { GS:MS 70:30 } \\
\text { GS:MS 30:70 }\end{array}$ & $70: 30$ & $\begin{array}{l}3 \\
2\end{array}$ & $\begin{array}{r}0 \\
-2\end{array}$ & $\begin{array}{l}-3 \\
-4\end{array}$ & $\begin{array}{r}-4 \\
3\end{array}$ & $\begin{array}{l}\text { NR } \\
\text { NR }\end{array}$ & $\begin{array}{l}13.0 \\
12.6\end{array}$ & $\begin{array}{l}13.3 \\
12.1\end{array}$ & $\begin{array}{r}2 \\
-4\end{array}$ & Hart et al. 2015 \\
\hline $\begin{array}{l}\text { Maize meal, } \\
\text { Soya bean hulls }\end{array}$ & $\begin{array}{l}\text { Less maize meal, } \\
\text { more soya bean hulls }\end{array}$ & $\begin{array}{l}28 \text { vs } 24^{4} \\
28 \text { vs } 24^{5}\end{array}$ & $\begin{array}{l}\text { MS:LH:GH 55:25:20 } \\
\text { MS:LH:GH 55:25:20 }\end{array}$ & $50: 50$ & $\begin{array}{r}0 \\
-6\end{array}$ & $\begin{array}{r}3 \\
-8\end{array}$ & $\begin{array}{r}3 \\
-2\end{array}$ & $\begin{array}{r}1 \\
10\end{array}$ & $\begin{array}{l}0 \\
1\end{array}$ & $\begin{array}{l}13.5 \\
12.4\end{array}$ & $\begin{array}{l}12.6 \\
13.2\end{array}$ & $\begin{array}{r}-8 \\
5\end{array}$ & Pirondini et al. 2015 \\
\hline $\begin{array}{l}\text { Sugar beet pulp, wheat } \\
\text { bran, palm kernel cake }\end{array}$ & Oats, barley, wheat & $\begin{array}{l}15 \text { vs } 3 \\
15 \text { vs } 3\end{array}$ & $\begin{array}{l}\text { Early GS } \\
\text { Late GS }\end{array}$ & $66: 34$ & $\begin{array}{l}5 \\
2\end{array}$ & $\begin{array}{l}1 \\
7\end{array}$ & $\begin{array}{r}-4 \\
2\end{array}$ & $\begin{array}{r}-2 \\
1\end{array}$ & $\begin{array}{l}\text { NR } \\
\text { NR }\end{array}$ & $\begin{array}{l}13.1 \\
14.0\end{array}$ & $\begin{array}{l}13.0 \\
13.9\end{array}$ & $\begin{array}{l}1 \\
1\end{array}$ & Pang et al. 2018 \\
\hline $\begin{array}{l}\text { Beet pulp, soya bean } \\
\text { hull, dried distillers maize } \\
\text { grains, wheat bran }\end{array}$ & $\begin{array}{c}\text { Wheat, maize grain, } \\
\text { wheat middling, } \\
\text { wheat starch }\end{array}$ & $\begin{array}{l}23 \text { vs } 6^{6} \\
23 \text { vs } 6^{7}\end{array}$ & $\begin{array}{l}\text { GS:GH 85:15 } \\
\text { GS:GH 85:15 }\end{array}$ & $50: 50$ & $\begin{array}{l}-3 \\
-4\end{array}$ & $\begin{array}{l}-3 \\
-1\end{array}$ & $\begin{array}{l}0 \\
3\end{array}$ & $\begin{array}{l}9 \\
1\end{array}$ & $\begin{array}{l}-13 \\
-14\end{array}$ & $\begin{array}{l}14.9 \\
15.3\end{array}$ & $\begin{array}{l}13.3 \\
11.9\end{array}$ & $\begin{array}{l}-11 \\
-22\end{array}$ & Bougouin et al. 2018 \\
\hline No protein feed & Rapeseed meal & $\begin{array}{l}16 \text { vs } 15 \\
17 \text { vs } 15 \\
19 \text { vs } 15 \\
17 \text { vs } 16 \\
19 \text { vs } 16 \\
19 \text { vs } 16\end{array}$ & $\begin{array}{l}\text { GS:RCS } 70: 30 \\
\text { GS:RCS } 70: 30 \\
\text { GS:RCS } 70: 30 \\
\text { GS:RCS } 30: 70 \\
\text { GS:RCS 30:70 } \\
\text { GS:RCS } 30: 70\end{array}$ & $60: 40$ & $\begin{array}{r}5 \\
10 \\
10 \\
4 \\
9 \\
7\end{array}$ & $\begin{array}{r}8 \\
10 \\
6 \\
3 \\
4 \\
7\end{array}$ & $\begin{array}{r}3 \\
0 \\
-4 \\
-1 \\
-5 \\
0\end{array}$ & $\begin{array}{r}-1 \\
-14 \\
-22 \\
-4 \\
-14 \\
-20\end{array}$ & $\begin{array}{l}\text { NR } \\
\text { NR } \\
\text { NR } \\
\text { NR } \\
\text { NR } \\
\text { NR }\end{array}$ & $\begin{array}{l}16.7 \\
16.7 \\
16.7 \\
17.8 \\
17.8 \\
17.8\end{array}$ & $\begin{array}{l}15.6 \\
15.2 \\
14.9 \\
15.0 \\
16.4 \\
16.3\end{array}$ & $\begin{array}{r}-7 \\
-9 \\
-11 \\
-16 \\
-8 \\
-8\end{array}$ & Gldlund et al. 2017 \\
\hline $\begin{array}{l}\text { Less soya bean protein } \\
\text { Less soya bean protein, } \\
\text { rapeseed meal }\end{array}$ & $\begin{array}{l}\text { More soya bean protein } \\
\text { More soya bean protein, } \\
\text { rapeseed meal }\end{array}$ & $\begin{array}{l}16 \text { vs } 14 \\
18 \text { vs } 14 \\
16 \text { vs } 14 \\
18 \text { vs } 14\end{array}$ & $\begin{array}{l}\text { GS:MS 75:25 } \\
\text { GS:MS 75:25 } \\
\text { GS:MS 25:75 } \\
\text { GS:MS 25:75 }\end{array}$ & $50: 50$ & $\begin{array}{l}8 \\
0 \\
2 \\
5\end{array}$ & $\begin{array}{l}1 \\
6 \\
0 \\
2\end{array}$ & $\begin{array}{l}-6 \\
6 \\
-1 \\
-3\end{array}$ & $\begin{array}{l}-10 \\
-22 \\
-13 \\
-24\end{array}$ & $\begin{array}{l}\text { NR } \\
\text { NR } \\
\text { NR } \\
\text { NR }\end{array}$ & $\begin{array}{l}16.7 \\
16.7 \\
17.8 \\
17.8\end{array}$ & $\begin{array}{l}15.6 \\
15.2 \\
15.0 \\
16.4\end{array}$ & $\begin{array}{r}-7 \\
-9 \\
-16 \\
-8\end{array}$ & Reynolds et al. $2010^{8}$ \\
\hline $\begin{array}{l}\text { Protein source } \\
\text { Soya bean meal }\end{array}$ & Rapeseed meal & $\begin{array}{l}\text { Protein } \\
19 \text { vs } 19\end{array}$ & GS & $60: 40$ & 2 & 2 & 0 & 5 & NR & 16.9 & 16.3 & -4 & Gidlund et al. 2015 \\
\hline
\end{tabular}




\begin{tabular}{|c|c|c|c|c|c|c|c|c|c|c|c|c|c|}
\hline Soya bean meal & $\begin{array}{l}\text { Faba bean milled } \\
\text { Faba bean rolled }\end{array}$ & $\begin{array}{l}16 \text { vs } 16 \\
16 \text { vs } 16\end{array}$ & $\begin{array}{l}\text { LS:MS 65:35 } \\
\text { LS:MS 65:35 }\end{array}$ & $55: 45$ & $\begin{array}{l}0 \\
1\end{array}$ & $\begin{array}{l}-2 \\
-2\end{array}$ & $\begin{array}{l}-2 \\
-3\end{array}$ & $\begin{array}{l}-3 \\
-3\end{array}$ & $\begin{array}{l}1 \\
9\end{array}$ & $\begin{array}{l}15.0 \\
15.0\end{array}$ & $\begin{array}{l}15.2 \\
15.4\end{array}$ & $\begin{array}{l}1 \\
3\end{array}$ & Cherif et al. 2018 \\
\hline $\begin{array}{l}\text { Soya bean meal: } \\
\text { rapeseed meal } 65: 35^{10}\end{array}$ & $\begin{array}{c}\text { Faba bean } 16 \% \\
33 \% \\
47 \%\end{array}$ & $\begin{array}{l}16 \text { vs } 16 \\
16 \text { vs } 16 \\
16 \text { vs } 16\end{array}$ & $\begin{array}{l}\text { GS } \\
\text { GS } \\
\text { GS }\end{array}$ & $60: 40$ & $\begin{array}{r}0 \\
0 \\
-1\end{array}$ & $\begin{array}{l}5 \\
0 \\
1\end{array}$ & $\begin{array}{r}5 \\
-1 \\
2\end{array}$ & $\begin{array}{r}5 \\
2 \\
-8\end{array}$ & $\begin{array}{l}\text { NR } \\
\text { NR } \\
\text { NR }\end{array}$ & $\begin{array}{l}17.6 \\
17.6 \\
17.6\end{array}$ & $\begin{array}{l}15.9 \\
16.2 \\
16.9\end{array}$ & $\begin{array}{l}-9 \\
-8 \\
-4\end{array}$ & Johnston et al. 2019 \\
\hline Rapeseed meal & $\begin{array}{c}\text { Faba bean } \\
\text { Pea }\end{array}$ & $\begin{array}{l}19 \text { vs } 19 \\
18 \text { vs } 19\end{array}$ & $\begin{array}{l}\text { GS } \\
\text { GS }\end{array}$ & $60: 40$ & $\begin{array}{r}-2 \\
0\end{array}$ & $\begin{array}{l}-4 \\
-6\end{array}$ & $\begin{array}{l}-3 \\
-6\end{array}$ & $\begin{array}{r}4 \\
-6\end{array}$ & $\begin{array}{l}\text { NR } \\
\text { NR }\end{array}$ & $\begin{array}{l}15.2 \\
15.2\end{array}$ & $\begin{array}{l}16.1 \\
16.7\end{array}$ & $\begin{array}{r}6 \\
10\end{array}$ & Ramin et al. 2017 \\
\hline
\end{tabular}

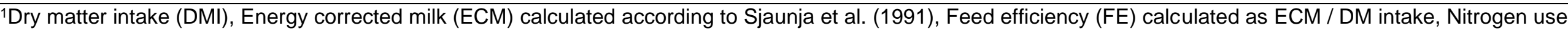

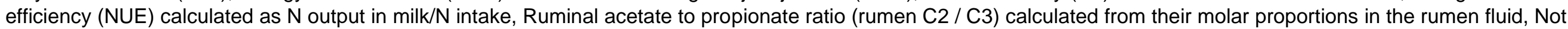

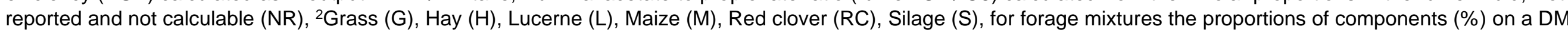

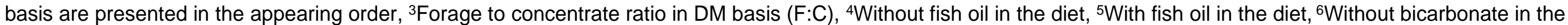

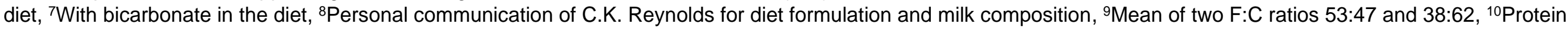
feed mixture containing $65 \%$ of soya bean meal and $35 \%$ of rapeseed meal on a DM basis 
Table 5. Fatty acid composition of tank milk (adapted from Halmemies-Beauchet-Filleau et al., 2019)

\begin{tabular}{|c|c|c|c|}
\hline Fatty acid, $\mathrm{g} / 100 \mathrm{~g}$ total fatty acids & Control diet & Test diet & Change in \% \\
\hline 10:0 & 3.9 & 2.0 & -49 \\
\hline $12: 0$ & 4.6 & 2.2 & -52 \\
\hline 14:0 & 13 & 8.5 & -35 \\
\hline 16:0 & 31 & 21 & -31 \\
\hline 18:0 & 9.7 & 18 & +82 \\
\hline $18: 1 n-9$ & 16 & 28 & +70 \\
\hline $18: 2 n-6$ & 1.3 & 1.1 & \\
\hline $18: 3 n-3$ & 0.4 & 0.4 & \\
\hline Total saturated fatty acids & 74 & 61 & -17 \\
\hline Total monounsaturated fatty acids & 23 & 36 & +58 \\
\hline Total polyunsaturated fatty acids & 2.6 & 2.3 & \\
\hline Total trans fatty acids & 3.6 & 5.0 & \\
\hline
\end{tabular}




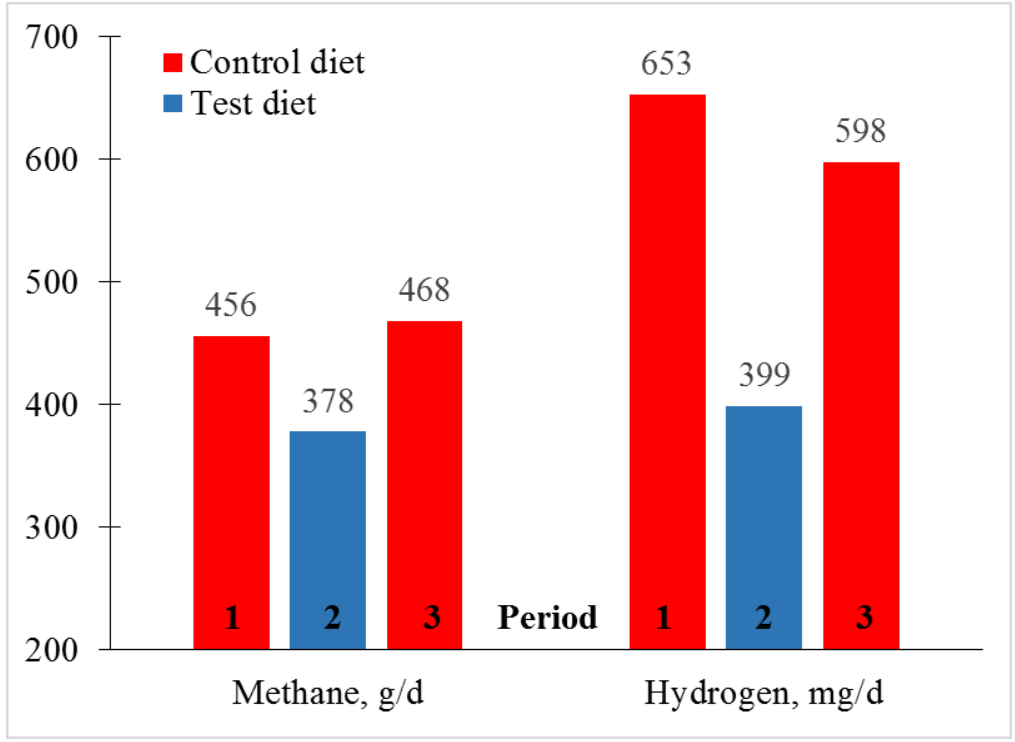

Figure 1. Ruminal gas emissions of dairy cows fed control diet in period 1, test diet in period 2 and again control diet in period 3 (adapted from Halmemies-Beauchet-Filleau et al., 2019) 